\title{
G eochemical and isotopic constraints on subduction polarity, magma sources, and palaeogeography of the Kohistan intra-oceanic arc, northern Pakistan H imalaya
}

\author{
M. ASIF KHAN ${ }^{1}$, ROBERT J. STERN ${ }^{2}$, ROBERT F. GRIBBLE ${ }^{2} \& B R I A N F$. WINDLEY ${ }^{3}$ \\ ${ }^{1} \mathrm{C}$ entre for Excellence in Geology, P eshawar U niversity, P eshawar, Pakistan \\ ${ }^{2} \mathrm{C}$ enter for Lithospheric Studies, U niversity of Texas at Dallas, Box 830688, Richardson, TX 75083-0688, USA \\ (e-mail: rjstern@utdallas.edu) \\ ${ }^{3}$ D epartment of Geology, U niversity of L eicester, L eicester LE $17 R \mathrm{H}, \mathrm{UK}$
}

\begin{abstract}
Geochemical and isotopic data are presented for 18 representative samples from the intraoceanic phase of the $\mathrm{K}$ ohistan arc. A restricted range of initial ${ }^{87} \mathrm{Sr} /{ }^{86} \mathrm{Sr}(0.7036-0.7066)$ and $\varepsilon \mathrm{N} \mathrm{d}(+2.8$ to +7.4$)$ along with measured ${ }^{206} \mathrm{~Pb} /{ }^{204} \mathrm{~Pb}(18.0-18.6)$ are consistent with formation of the arc complex in an intra-oceanic setting. The isotopic data demonstrate the involvement of enriched, DUPAL-type mantle, suggesting that the K ohistan arc formed at or south of the present equator. Subduction polarity inferred from geochemical and isotopic data indicate that the Chalt Volcanics and $\mathrm{K}$ amila A mphibolites represent a forearc and backarc basin sequence, respectively. These inferences are most simply resolved with a tectonic model whereby the intra-oceanic K ohistan arc evolved over a south-dipping subduction zone, implying that K ohistan and India moved northwards on the same plate, although separated, during much of Cretaceous time. Collision of K ohistan with the $\mathrm{K}$ arakorum caused a new, north-dipping subduction zone to form on the south side of $\mathrm{K}$ ohistan, leading to collision with India in early Tertiary time.
\end{abstract}

Keywords: H imalayas, Pakistan, island arcs, isotopes.

The K ohistan terrane of northern Pakistan is a superb example of juvenile crust that formed by magmatic additions at an intra-oceanic convergent margin ( $\mathrm{H}$ amilton 1994). It is particularly important to tectonicists because its formation and accretion history constrains the Cretaceous palaeogeography of the $\mathrm{Neotethys,} \mathrm{and} \mathrm{to} \mathrm{igneous} \mathrm{geochemists}$ because it provides a complete and well-exposed section of primitive arc crust. Almost no isotopic data has been previously reported for the $\mathrm{K}$ ohistan intraoceanic arc terrane, and several important aspects about its tectonic significance remain controversial, particularly how wide was the oceanic seaway that separated it from Asia, and what was Kohistan's subduction polarity? We report here new major and trace element and isotopic compositions for igneous rocks that formed during the evolution of Kohistan as an intra-oceanic arc, and use these data to (1) confirm that $\mathrm{K}$ ohistan represents an intra-oceanic arc; (2) demonstrate that, prior to collision with the $\mathrm{K}$ arakorum terrane, the $\mathrm{K}$ ohistan arc faced north over a south-dipping subduction zone; and (3) infer that the K ohistan intra-oceanic arc originated near the present location of the DUPAL isotopic anomaly, at near equatorial latitudes.

\section{G eological setting}

The Kohistan terrane is located in northern Pakistan and is bounded to the north by the Shyok (or N orthern) Suture and to the south by the Indus Suture (Fig. 1). Sedimentary sequences indicate that formation of the intra-oceanic $\mathrm{K}$ ohistan arc began in Early Cretaceous time ( $\mathrm{Y}$ asin G roup carbonates of A ptian-A lbian age; Pudsey 1986), consistent with $\mathrm{Ar} / \mathrm{Ar}$ and $\mathrm{Rb} / \mathrm{Sr}$ ages indicating that the bulk of the igneous infrastructure formed between 110 and $90 \mathrm{M} \mathrm{a}$ (Schärer et al. 1984; Petterson \& W indley 1985; Treloar et al.
1989). The inference that K ohistan originated as an intraoceanic arc results from its mafic bulk composition, presence of pillowed lavas and marine sediments, low-K nature of associated felsic rocks, absence of continental crust or detritus, and separation of the inferred intra-oceanic arc of K ohistan from continental crust to the north and south by unequivocal suture zones. K ohistan and L adakh comprise correlative parts of this Cretaceous intraoceanic arc separated by the late Cenozoic $\mathrm{N}$ anga Parbat- $\mathrm{H}$ aramosh uplift. The intraoceanic phase of $\mathrm{K}$ ohistan lasted until sometime between 102 and $85 \mathrm{M}$ a, when $\mathrm{K}$ ohistan collided with the $\mathrm{K}$ arakorum ( $\mathrm{A}$ sia) across the Shyok Suture (Treloar et al. 1996). F rom this time until collision with India about $50 \mathrm{M}$ a ago, $\mathrm{K}$ ohistan existed as an A ndean-type margin. F or a current overview of the geology of K ohistan see Treloar et al. (1996). This report focuses on the intra-oceanic phase of K ohistan.

The intra-oceanic arc crust of $K$ ohistan consists of five principal units, extending from the Indus Suture in the south to the Shyok Suture in the north (Fig. 1): (1) basal ultramafic-mafic cumulates (Jijal Ultramafics); (2) Kamila A mphibolite; (3) Chilas Complex of mafic to intermediate plutonic rocks; (4) early bimodal suite of intrusive rocks (Stage 1 of Petterson \& Windley 1985) and Gilgit gneisses; and (5) Chalt Volcanics (K han et al. 1993). The early bimodal suite is a small part of the region shown as 'K ohistan batholith' in Fig. 1. The bulk of the Kohistan batholith formed after collision of $\mathrm{K}$ ohistan and $\mathrm{K}$ arakorum, during the A ndeanmargin phase of $K$ ohistan, and is of no concern to this report. We report geochemical and isotopic data on Kamila amphibolites, Chilas Complex intrusive rocks, and Chalt Volcanics.

The $\mathrm{K}$ amila Amphibolite belt is a composite mass dominated by amphibolite-facies meta-plutonic and metavolcanic rocks. Hornblende Ar-Ar cooling ages of about 


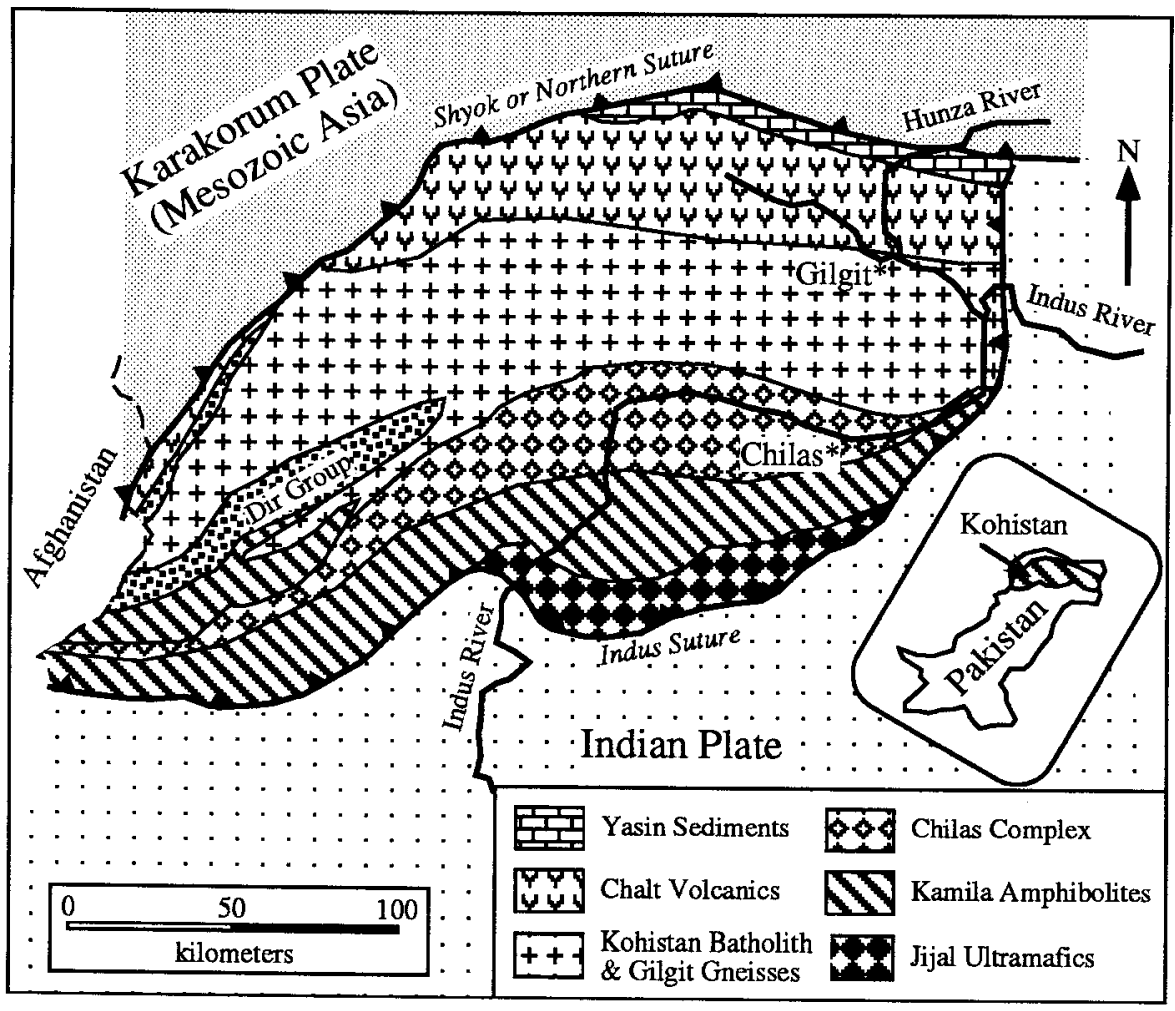

Fig. 1. Simplified geological map of the $\mathrm{K}$ ohistan terrane (modified after Coward et al. 1986).
$80 \mathrm{M} \mathrm{a}$ (T reloar et al. 1989) indicate that regional amphibolite facies conditions existed prior to this time. Two types of amphibolites are identified in the field: (1) fine- to mediumgrained amphibolites, either homogeneous or banded and (2) homogeneous, medium-to coarse-grained amphibolites (J an 1988; Treloar et al. 1990). The former are thought to be metamorphosed mafic to intermediate volcanics, whereas the latter are interpreted as metamorphosed gabbros and diorites. Our study was concerned with the metavolcanic amphibolites; we report no data for the second group. The K amila metavolcanic amphibolites are subdivided into HFSE-enriched and -depleted groups, and are referred to as 'E-type' and 'D -type' metavolcanic amphibolites by K han et al. (1993). E-type amphibolites have M OR B-like major and trace element compositions and do not show spikes in normalized trace element patterns characteristic of subduction-related igneous rocks. In addition they show REE patterns with modest depletions in LREE. In contrast, D -type amphibolites show normalized trace element patterns consistent with the participation of a 'subduction component' (Pearce 1984). K amila amphibolites derived from metamorphosed plutonic rocks show a very strong 'subduction component', with high $\mathrm{Ba} / \mathrm{N} \mathrm{b}$. $\mathrm{K}$ amila metaplutonic amphibolites are compositionally very similar to gabbronorites of the Chilas Complex. $\mathrm{K}$ han et al. (1993) concluded that all three varieties of K amila amphibolites were derived from a mantle source that was enriched in incompatible trace elements.

The Chilas Complex is more than $300 \mathrm{~km}$ long and up to $40 \mathrm{~km}$ wide, defining the spine of the K ohistan terrane. The Chilas Complex is subdivided into 'main gabbronorites' and a 'UMA association' by K han et al. (1989). Gabbronorites comprise the vast bulk of the Chilas Complex; the distinctive cumulate ultramafic, mafic, and anorthositic rocks of the UMA association formed later. Gabbronorites define a calc-alkaline suite that range from about 51 to $59 \% \mathrm{SiO}_{2}$, comparable to island-arc non-cumulates of Beard (1986). They show the distinctive chemical characteristics of convergent margin magmas, especially strongly positive spikes for $\mathrm{Ba}, \mathrm{K}$, and $\mathrm{Sr}$, and negative $\mathrm{Nb}$ anomalies. They have modest LREE-enrichments $\left((\mathrm{Ce} / \mathrm{Y} \mathrm{b})_{n}=2-3.5\right)$, with REE contents of about $10 \times$ chondritic abundances. The rocks cooled and equilibrated under $\mathrm{P}-\mathrm{T}$ conditions of the pyroxene granulite facies, estimated at $750-850^{\circ} \mathrm{C}$ and $5-6.5 \mathrm{kbar}(\mathrm{J}$ an $\& \mathrm{H}$ owie 1980). In spite of the close temporal and spatial affinities of the two principal Chilas Complex components, significant differences in mineral compositions exist between gabbronorites (Olivine absent, magnetiteilmenite, $A n_{40}-A n_{64}$ ) and $U M A$ (Olivine abundant, $\mathrm{Cr}$-spinel, $A \mathrm{n}_{83}-\mathrm{A} \mathrm{n}_{99}$ ). The $\mathrm{Chilas}$ Complex was emplaced at C. $100 \mathrm{M}$ a into high levels of the deformed arc. F or this report, we accept the Chilas Complex as developed during the intra-oceanic phase of $\mathrm{K}$ ohistan arc evolution, although Treloar et al. (1996) conclude that the Chilas Complex was emplaced after K ohistan collided with the K arakorum.

The Chalt Volcanics occupy a $330 \mathrm{~km} \times 30 \mathrm{~km}$ belt along northernmost $K$ ohistan. The upper part of these volcanics are interbedded with the $Y$ asin sediments of A ptian-A Ibian age. A bundant pillowed lavas demonstrate that some if not all of these lavas erupted subaqueously. The $Y$ asin and Chalt are strongly deformed and modestly metamorphosed, from lower greenschist facies in the west to lower amphibolite facies in the east (Petterson \& W indley 1991). A significant compositional difference is observed along the strike of the belt, with a high-Mg suite encountered in the Hunza Valley (where the present suite was obtained) and a low to intermediate $\mathrm{M} \mathrm{g}$ calc-alkaline sequence found to the west. Boninite is common in the Hunza Valley section along with some tholeiitic basalts and abundant felsic lavas. 
Table 1. M ajor* and trace element and isotopic data, Kamila A mphibolites

\begin{tabular}{|c|c|c|c|c|c|c|}
\hline & \multicolumn{3}{|c|}{ E-type } & \multicolumn{3}{|c|}{ D-type } \\
\hline & A 83 & A 86 & A 93 & A 119 & A 121 & A 125 \\
\hline $\mathrm{SiO}_{2}$ & 51.2 & 48.0 & 48.7 & 49.5 & 50.3 & 48.7 \\
\hline $\mathrm{TiO}_{2}$ & 2.24 & 2.13 & 1.86 & 0.69 & 0.47 & 0.75 \\
\hline $\mathrm{Al}_{2} \mathrm{O}_{3}$ & 14.31 & 14.44 & 14.71 & 15.90 & 16.36 & 19.11 \\
\hline $\mathrm{Fe}_{2} \mathrm{O}_{3}^{\top}$ & 14.67 & 14.08 & 13.06 & 9.08 & 8.93 & 9.15 \\
\hline $\mathrm{MgO}$ & 5.11 & 6.11 & 6.90 & 11.17 & 8.18 & 6.50 \\
\hline $\mathrm{CaO}$ & 9.63 & 11.64 & 11.82 & 9.83 & 12.28 & 12.01 \\
\hline $\mathrm{Na}_{2} \mathrm{O}$ & 2.40 & 3.09 & 2.66 & 3.22 & 2.81 & 2.52 \\
\hline $\mathrm{K}_{2} \mathrm{O}$ & 0.26 & 0.32 & 0.08 & 0.38 & 0.57 & 1.06 \\
\hline $\mathrm{P}_{2} \mathrm{O}_{5}$ & 0.19 & 0.21 & 0.17 & 0.19 & 0.12 & 0.17 \\
\hline $\mathrm{Ni}$ & 22 & 75 & 58 & 207 & 56 & 83 \\
\hline $\mathrm{Zr}$ & 139 & 149 & 114 & 41 & 23 & 53 \\
\hline$Y$ & 53 & 52 & 40 & 18 & 13 & 18 \\
\hline $\mathrm{Nb}$ & 4.8 & 6.2 & 4.3 & 2.6 & 1.0 & 5.0 \\
\hline $\mathrm{Rb}$ & 2 & 2 & 1 & 9 & 10 & 27 \\
\hline $\mathrm{Sr}$ & 150 & 137 & 169 & 233 & 268 & 257 \\
\hline $\mathrm{N} \mathrm{d} \dagger$ & 15.4 & 16.6 & 12.7 & 8.4 & 5.8 & 14.0 \\
\hline Smt & 5.3 & 5.5 & 4.2 & 2.3 & 1.74 & 3.4 \\
\hline $\mathrm{Pb} \dagger$ & 3.28 & 2.01 & 0.57 & & & 7.03 \\
\hline $\mathrm{K} / \mathrm{Rb}$ & 1080 & 1330 & 660 & 350 & 470 & 330 \\
\hline $\mathrm{Sr} / \mathrm{Nd}$ & 9.7 & 8.3 & 13.3 & 27.7 & 46.2 & 18.4 \\
\hline${ }^{87} \mathrm{Sr} /{ }^{86} \mathrm{Sr}$ & 0.70388 & 0.70384 & 0.70366 & 0.70417 & 0.70467 & 0.70467 \\
\hline${ }^{87} \mathrm{Sr} /{ }^{86} \mathrm{Sr}_{\mathrm{i}}$ & 0.70381 & 0.70377 & 0.70363 & 0.70398 & 0.70449 & 0.70415 \\
\hline${ }^{143} \mathrm{~N} \mathrm{~d} /{ }^{144} \mathrm{~N} \mathrm{~d}$ & 0.51302 & 0.51299 & 0.51301 & 0.51284 & 0.51283 & 0.51274 \\
\hline$\varepsilon N \mathrm{~d}(120)$ & +7.4 & +7.0 & +7.4 & +4.7 & +4.2 & +2.9 \\
\hline${ }^{206} \mathrm{~Pb} /{ }^{204} \mathrm{~Pb}$ & 17.973 & 18.128 & 18.087 & 18.073 & 18.033 & 18.462 \\
\hline${ }^{207} \mathrm{~Pb} /{ }^{204} \mathrm{~Pb}$ & 15.561 & 15.497 & 15.456 & 15.527 & 15.535 & 15.586 \\
\hline${ }^{208} \mathrm{~Pb} /{ }^{204} \mathrm{~Pb}$ & 37.951 & 38.080 & 37.979 & 38.170 & 38.039 & 38.644 \\
\hline$\Delta^{207} \mathrm{~Pb} \neq$ & 12 & 4.1 & 0.4 & 7.7 & 8.9 & 9.4 \\
\hline$\Delta^{208} \mathrm{~Pb} \neq$ & 59 & 54 & 48 & 69 & 61 & 70 \\
\hline
\end{tabular}

*M ajor element totals normalized to $100 \%$, anhydrous.

†A nalysis by isotope dilution.

${ }^{87} \mathrm{Sr}^{86} \mathrm{Sr}_{\mathrm{i}}, \varepsilon \mathrm{N} \mathrm{d}(120)$ calculated using $\mathrm{t}=120 \mathrm{M}$ a and $\mathrm{Rb} / \mathrm{Sr}, \mathrm{Sm} / \mathrm{N}$ d listed above.

$\ddagger D$ eviations from $\mathrm{N}$ orthern $\mathrm{H}$ emisphere R eference $\mathrm{L}$ ine ( $\mathrm{H}$ art 1984).

\section{A nalytical techniques}

$M$ ajor- and trace-element analyses presented in Tables 1, 2, and 3 were obtained using standard XRF spectrometry techniques. The samples of $\mathrm{K}$ amila A mphibolite and the $\mathrm{C}$ hilas Complex were analysed at the U niversity of Oklahoma, using a Rigaku XRF, while those from the Chalt Volcanics were analysed at the $U$ niversity of L eicester, using Philips PW 1450 automatic XRF. Similar analytical techniques and standards were used at the two laboratories. $M$ ajor elements were determined from glass fusion beads (made using a lithium tetraborate/ lithium metaborate flux; rock:flux ratio $1: 5$ ) analysed by using a $\mathrm{R} h$ anode $X$-ray tube. Trace element concentrations were determined on

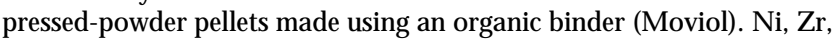
$\mathrm{Nb}, \mathrm{R} b, \mathrm{Sr}, \mathrm{Y}$ determinations were made using a $\mathrm{R} \mathrm{h}$ anode $\mathrm{X}$-ray tube with mass absorption corrections applied using the intensities of the $\mathrm{Rh} \mathrm{K} \alpha$ Compton scatter peak (H arvey \& A tkins 1982). Determinations of $\mathrm{Cr}$ and $\mathrm{Ba}$ used a $\mathrm{W}$ anode $\mathrm{X}$-ray tube with mass absorption corrections applied using the intensities of the $W L \alpha$ R ayleigh scatter peak and $\mathrm{Fe} \mathrm{K} \alpha$ to cross the $\mathrm{F}$ e-absorption edge after the technique of $\mathrm{N}$ esbitt et al. (1976). Detections limits (2 sigma) are approximately $1 \mathrm{ppm}$ for $\mathrm{Cr}, \mathrm{Rb}, \mathrm{Sr}, \mathrm{Zr}, \mathrm{Nb}$ and $\mathrm{Y}$, and $2 \mathrm{ppm}$ for $\mathrm{N} \mathrm{i}, \mathrm{Cr}$ and $\mathrm{Ba}$.

Concentrations of $\mathrm{Nd}, \mathrm{Sm}$, and $\mathrm{Pb}$ were determined by isotope dilution at UTD. Standard isotope dilution and cation exchange techniques were used to separate $\mathrm{Sr}$, and LREE (Nd\& Sm). A procedure modified after R ichard et al. (1976) was used to separate N d from $\mathrm{Sm}$ for isotope composition runs. The $\mathrm{Pb}$ separation procedure is reported in $M$ anton (1988), with an initial anionic column separation. Total processing blanks were: $<140 \mathrm{pg} \mathrm{Pb} ;<700 \mathrm{pg} \mathrm{N} \mathrm{d}$; and $<1 \mathrm{ng} \mathrm{Sr}$. I sotopic compositions were determined with a Finnigan MAT 261 multi-collector thermal ionization mass spectrometer; $\mathrm{N} \mathrm{d}$ was analysed in the dynamic multicollection mode, whereas $\mathrm{Sr}$ and $\mathrm{Pb}$ were analysed in the static multicollection mode. $\mathrm{Sr}$ isotopic compositions were fractionation-corrected to ${ }^{86} \mathrm{Sr} /{ }^{88} \mathrm{Sr}=0.1194$ and adjusted relative to $\mathrm{E} \& \mathrm{~A} \mathrm{SrCO}_{3}{ }^{87} \mathrm{Sr} /{ }^{86} \mathrm{Sr}=0.70800$. $\mathrm{Nd}$ isotopic compositions were fractionation-corrected to ${ }^{146} \mathrm{~N} \mathrm{~d} /{ }^{144} \mathrm{~N} \mathrm{~d}=0.7219$ and $\varepsilon \mathrm{N} \mathrm{d}$ was calculated using the $\varepsilon N$ d values of Pier et al. (1989) for BCR -1 and U CSD standards. The standard values with reproducibility during the year in which isotopic analyses were carried out ( \pm 1 standard deviation, with digits corresponding to the last decimal places reported) were: $E \& A$ $\mathrm{SrCO}_{3}{ }^{87} \mathrm{Sr} /{ }^{86} \mathrm{Sr}=0.708020$ (35; $\mathrm{n}=32$ ), U CSD ${ }^{143} \mathrm{~N} \mathrm{~d} /{ }^{144} \mathrm{~N} \mathrm{~d}=0.511848$ $(14 ; n=26)$, and BCR $-1{ }^{143} \mathrm{Nd} /{ }^{144} \mathrm{Nd}=0.512620(8 ; n=8) ; N B S 981$ (with $0.15 \%$ per amu $\mathrm{Pb}$ fractionation correction) ${ }^{206} \mathrm{~Pb} /{ }^{204} \mathrm{~Pb}=16.943$ (13), ${ }^{207} \mathrm{~Pb} /{ }^{204} \mathrm{~Pb}=15.495$ (17), ${ }^{208} \mathrm{~Pb} /{ }^{204} \mathrm{~Pb}=36.736$ (50) for 16 analyses.

$\mathrm{Sr}$ and $\mathrm{N}$ d isotopic compositions listed in Tables 1 to 3 are reported both as measured following fractionation correction $\left({ }^{143} \mathrm{~N} \mathrm{~d} /{ }^{144} \mathrm{Nd}\right)$ and, in the case of $\mathrm{Sr}$, adjustment to a value of 0.70800 for $\mathrm{E} \& \mathrm{~A} \mathrm{SrCO}_{3}$ ${ }^{87} \mathrm{Sr} /{ }^{86} \mathrm{Sr}$, as well as initial isotopic compositions, corrected for $120 \mathrm{M} \mathrm{a}$ of radiogenic growth using values of ${ }^{147} \mathrm{Sm} /{ }^{144} \mathrm{~N} \mathrm{~d}$ and ${ }^{87} \mathrm{R} \mathrm{b} /{ }^{86} \mathrm{Sr}$ from element abundances listed in Tables 1 to 3 . Initial isotopic compositions are reported either as ${ }^{87} \mathrm{Sr}^{86} \mathrm{Sr}_{\mathrm{i}}$ or as $\varepsilon \mathrm{Nd}_{(120)}$. $\mathrm{Pb}$ isotopic compositions are recalculated using the $\Delta$ notation of $\mathrm{H}$ art (1988), which specifies the extent to which ${ }^{207} \mathrm{~Pb} /{ }^{204} \mathrm{~Pb}$ and ${ }^{208} \mathrm{~Pb} /{ }^{204} \mathrm{~Pb}$ are distinct from a reference line defined by oceanic basalts from the northern hemisphere. This notation is used because it is an effective way to identify igneous rocks derived from certain mantle reservoirs such as the DUPAL source. Because $U$ and Th concentrations have not been determined, the $\mathrm{Pb}$ isotopic compositions could not be 
Table 2. M ajor* and trace element and isotopic data, Chilas Complex

\begin{tabular}{|c|c|c|c|c|}
\hline & \multicolumn{2}{|c|}{ UMA } & \multicolumn{2}{|c|}{ M ain gabbronorites } \\
\hline & IK 1007 & IK 1009 & IK 1012 & IK 1017 \\
\hline $\mathrm{SiO}_{2}$ & 45.9 & 43.0 & 52.5 & 58.4 \\
\hline $\mathrm{TiO}_{2}$ & 0.07 & 0.22 & 1.24 & 0.84 \\
\hline $\mathrm{Al}_{2} \mathrm{O}_{3}$ & 24.09 & 3.77 & 18.28 & 17.80 \\
\hline $\mathrm{Fe}_{2} \mathrm{O}_{3}^{\top}$ & 4.67 & 18.95 & 9.45 & 7.93 \\
\hline $\mathrm{MnO}$ & 0.07 & 0.24 & 0.12 & 0.12 \\
\hline $\mathrm{MgO}$ & 9.45 & 30.42 & 5.31 & 3.91 \\
\hline $\mathrm{CaO}$ & 15.41 & 3.37 & 9.44 & 7.39 \\
\hline $\mathrm{N} \mathrm{a}_{2} \mathrm{O}$ & 0.35 & 0.00 & 2.74 & 3.04 \\
\hline $\mathrm{K}_{2} \mathrm{O}$ & 0.01 & 0.00 & 0.66 & 0.35 \\
\hline $\mathrm{P}_{2} \mathrm{O}_{5}$ & 0.01 & 0.02 & 0.25 & 0.18 \\
\hline $\mathrm{Ni}$ & 169 & 819 & 33 & 18 \\
\hline $\mathrm{Cr}$ & 397 & 1208 & 56 & 36 \\
\hline $\mathrm{Zr}$ & 5 & 5 & 71 & 133 \\
\hline $\mathrm{Nb}$ & - & - & 3.7 & 4 \\
\hline $\mathrm{Rb}$ & $<1$ & $<1$ & 7 & $<1$ \\
\hline $\mathrm{Sr}$ & 427 & 64 & 403 & 446 \\
\hline $\mathrm{Ba}$ & 18 & 19 & 211 & 246 \\
\hline $\mathrm{Nd}+$ & 0.81 & 0.73 & 13.6 & 13.0 \\
\hline Smt & 0.25 & 0.25 & 3.56 & 3.29 \\
\hline $\mathrm{Pb} \dagger$ & - & - & - & - \\
\hline $\mathrm{K} / \mathrm{R} \mathrm{b}$ & - & - & 780 & - \\
\hline $\mathrm{Sr} / \mathrm{Nd}$ & 527 & 87.7 & 29.6 & 34.3 \\
\hline${ }^{87} \mathrm{Sr} /{ }^{86} \mathrm{Sr}$ & 0.70405 & 0.70404 & 0.70423 & 0.70412 \\
\hline${ }^{87} \mathrm{Sr} /{ }^{86} \mathrm{Sr}_{\mathrm{i}}$ & 0.70404 & 0.70396 & 0.70414 & 0.70411 \\
\hline${ }^{143} \mathrm{~N} \mathrm{~d} /{ }^{144} \mathrm{~N} \mathrm{~d}$ & 0.51280 & 0.51284 & 0.51274 & 0.51274 \\
\hline$\varepsilon N d(120)$ & +3.5 & +4.0 & +2.8 & +2.9 \\
\hline${ }^{206} \mathrm{~Pb} /{ }^{204} \mathrm{~Pb}$ & 18.526 & 18.574 & 18.554 & 18.526 \\
\hline${ }^{207} \mathrm{~Pb} /{ }^{204} \mathrm{~Pb}$ & 15.640 & 15.623 & 15.627 & 15.624 \\
\hline${ }^{208} \mathrm{~Pb} /{ }^{204} \mathrm{~Pb}$ & 38.762 & 38.671 & 38.783 & 38.746 \\
\hline$\Delta^{207} \mathrm{~Pb} \ddagger$ & 14 & 12 & 13 & 12 \\
\hline$\Delta^{208} \mathrm{~Pb} \neq$ & 74 & 59 & 72 & 72 \\
\hline
\end{tabular}

*M ajor element totals normalized to $100 \%$, anhydrous.

†A nalysis by isotope dilution.

${ }^{87} \mathrm{Sr} /{ }^{86} \mathrm{Sr}_{i}, \varepsilon \mathrm{Nd}(120)$ calculated using $\mathrm{t}=120 \mathrm{M}$ a and $\mathrm{Rb} / \mathrm{Sr}, \mathrm{Sm} / \mathrm{N} \mathrm{d}$ listed above.

$\ddagger D$ eviations from $\mathrm{N}$ orthern $\mathrm{H}$ emisphere $\mathrm{R}$ eference $\mathrm{L}$ ine ( $\mathrm{H}$ art 1984).

recalculated as initial ratios. H owever, the isotopic composition of $\mathrm{Pb}$ in the samples may still be a useful isotopic fingerprint for the following reasons: (1) relatively little isotopic growth is expected to have occurred (see modelled growth in Fig. 4); and (2) relatively modest fractionation of $\mathrm{U}, \mathrm{Th}$, and $\mathrm{Pb}$ is expected during generation of mafic melts from the mantle (Zartman \& D oe 1981). The Pb isotopic characteristics of $\mathrm{K}$ ohistan samples are similar to the DUPAL mantle reservoir, and this is not likely to be a result of post-eruption radiogenic growth.

\section{R esults}

The investigated $\mathrm{K}$ amila samples are all mafic, with a restricted range in silica (48-52\%) but with a much wider range in incompatible elements such as K (Fig. 2). The subdivision of the $\mathrm{K}$ amila metavolcanic amphibolites into $\mathrm{E}$-type (relatively high $\mathrm{Ti}$ and other HF SE such as $\mathrm{Zr}, \mathrm{Y}$, and $\mathrm{Nd}$; relatively low $\mathrm{K}_{2} \mathrm{O}, \mathrm{Rb}$, and $\mathrm{Sr}$ ) and $\mathrm{D}$-type is supported by trace element ratios ( $E$-type has high $K / R b=660-1330$ and low $\mathrm{Sr} / \mathrm{N} \mathrm{d}=8-13$ characteristic of MORB and ocean island basalt (OIB), whereas $D$-type has low $\mathrm{K} / \mathrm{R} \mathrm{b}=330-470$ and high $\mathrm{Sr} / \mathrm{N} \mathrm{d}=18-$ 46 , similar to that of modern convergent margin volcanic suites). A ll of these features are consistent with $E$-type $K$ amila metavolcanic amphibolites having a M OR B-like basaltic precursor, whereas D-type Kamila metavolcanic amphibolites have clear characteristics of supra-subduction zone igneous rocks. We will show that K amila D-type metavolcanics are similar in many respects to the rocks of the Chilas plutonic complex.

The isotopic data also distinguish between the two types of $\mathrm{K}$ amila metavolcanic amphibolites. $\mathrm{E}$-type samples have more radiogenic $\mathrm{Nd}\left(\varepsilon \mathrm{N} \mathrm{d}_{120 \mathrm{M} \mathrm{a}}=+7.0\right.$ to +7.4$)$ and less radiogenic initial $\mathrm{Sr}\left({ }^{87} \mathrm{Sr} /{ }^{86} \mathrm{Sr}=0.7036-0.7039\right)$ than the three $\mathrm{D}$-type samples $\left(\varepsilon \mathrm{N} \mathrm{d}_{120 \mathrm{M} \mathrm{a}}=+2.9\right.$ to $\left.+4.7 ;{ }^{87} \mathrm{Sr} /{ }^{86} \mathrm{Sr}=0.7041-0.7047\right)$. $\mathrm{E}$-type and $\mathrm{D}$-type amphibolites plot in distinct locations in a plot of $\mathrm{Sr}-\mathrm{Nd}$ isotopes (Fig. 3). The $\mathrm{Pb}$ isotopic compositions of $E$ - and D -type metavolcanics are similar ( $F$ ig. 4). K amila $\mathrm{E}$-type amphibolites have the most radiogenic $\mathrm{Nd}$ and least radiogenic $\mathrm{Sr}$ and ${ }^{206} \mathrm{~Pb} /{ }^{204} \mathrm{~Pb}$ of all the $\mathrm{K}$ ohistan samples that we have analysed. K amila D-type metavolcanic amphibolites are similar to Chilas samples in having relatively low ${ }_{\varepsilon} \mathrm{N} \mathrm{d}_{120 \mathrm{M} \mathrm{a}}$ and high ${ }^{87} \mathrm{Sr} /{ }^{86} \mathrm{Sr}$, although only one of the $\mathrm{D}$-type $K$ amila samples (A 125) has a similar Pb isotopic composition. A puzzling feature is that Kamila amphibolites have homogeneous and relatively non-radiogenic ${ }^{206} \mathrm{~Pb} /{ }^{204} \mathrm{~Pb}$ and ${ }^{208} \mathrm{~Pb} /{ }^{204} \mathrm{~Pb}$, but have variable ${ }^{207} \mathrm{~Pb} /{ }^{204} \mathrm{~Pb}$.

Of the four Chilas samples that were analysed, two are from the $\mathrm{M}$ ain $\mathrm{G}$ abbronorites and two are from the UMA. UMA samples are cumulates, so it is difficult to infer much regarding their petrotectonic setting from their chemical compositions. The gabbronorite samples on the other hand may approximate melt compositions; they are mafic to intermediate and belong to a low- $\mathrm{K}$ to moderate $\mathrm{K}$ suite. $\mathrm{G}$ abbronorites have high $\mathrm{K} / \mathrm{Rb}$ and $\mathrm{Sr} / \mathrm{Nd}$; we can infer from their Sm and $\mathrm{Nd}$ abundances that these were moderately enriched in LREE. The isotopic composition of the four C hilas samples is very homogeneous, with ${ }^{87} \mathrm{Sr} /{ }^{86} \mathrm{Sr}_{\mathrm{i}}=0.70396-0.70414, \varepsilon \mathrm{N} \mathrm{d}(120)=+2.8$ to +4.0 , and very homogenous $\mathrm{Pb}$. A long with one sample of D -type K amila amphibolite (A 125), the Chilas complex defines the relatively 'enriched' endmember of the K ohistan intraoceanic arc terrane. The Chilas Complex samples and some $\mathrm{D}$-type $\mathrm{K}$ amila amphibolites extend towards an EM I isotopic reservoir in $\mathrm{Sr}-\mathrm{N}$ d isotopic space, but extend towards $\mathrm{EM} \mathrm{II} \mathrm{in}$ $\mathrm{Pb}$ isotopic space.

The Chalt Volcanics define a compositionally heterogeneous group. They include low-K and medium- $K$ rocks of basaltic, boninitic, and rhyodacitic composition ( $\mathrm{Fig} .2)$. The suite is characterized by very low $\mathrm{TiO}_{2}$ and $\mathrm{Zr}$ contents $(<0.45 \%$ and $<80$ ppm, respectively). Chalt boninites and low-Ti basalts may contain very high contents of $\mathrm{M} \mathrm{gO}$ (up to $12.5 \%$ ), $\mathrm{N} \mathrm{i}$ (up to $400 \mathrm{ppm}$ ), and $\mathrm{Cr}$ (up to $1500 \mathrm{ppm}$ ). Boninitic samples (PL 28, N 138, N 161, and IK 580) have 10 to $12.5 \% \mathrm{CaO}$, and must therefore be classified as ' $\mathrm{H}$ igh $\mathrm{C}$ a boninites' according to Crawford et al. (1989). Basalts and boninites have very low abundances of $\mathrm{Sr}(<100 \mathrm{ppm}), \mathrm{Ba}(<40 \mathrm{ppm})$, and $\mathrm{Nd}$ $(<8 \mathrm{ppm})$.

Samples of the Chalt Volcanics that we analysed have homogeneous isotopic compositions of $\mathrm{Nd}(\varepsilon \mathrm{N} \mathrm{d}(120 \mathrm{Ma})=$ +6.3 to + 7.3) and $\mathrm{Pb}\left({ }^{206} \mathrm{~Pb} /{ }^{204} \mathrm{~Pb}=18.1-18.4 \Delta^{208} \mathrm{~Pb}=44-58\right.$; $\left.\Delta^{207} \mathrm{~Pb}=5-10\right)$. The 8 samples of $\mathrm{C}$ halt boninite, basalt, and rhyodacite fall between $\mathrm{K}$ amila and $\mathrm{C}$ hilas suites on plots of $\mathrm{Pb}$ isotopic compositions ( $\mathrm{F}$ ig. 4). The Chalt V olcanics define a much larger range on a plot of $\mathrm{Sr} \mathrm{v} . \mathrm{N}$ d isotopic compositions (Fig. 3), reflecting the larger range in ${ }^{87} \mathrm{Sr}^{86} \mathrm{Sr}_{\mathrm{i}}(0.7040-$ 0.7055). The Chalt Volcanics are metamorphosed submarine lavas, probably reflecting partial re-equilibration accompanying submarine hydrothermal metamorphism. Such 
T able 3. M ajor* and trace element and isotopic data, Chalt $\mathrm{V}$ olanics

\begin{tabular}{|c|c|c|c|c|c|c|c|c|}
\hline & PL 28 & PL 29 & N 115 & N 116 & N 138 & N 139 & N 161 & IK 580 \\
\hline $\mathrm{SiO}_{2}$ & 53.5 & 64.6 & 76.0 & 49.7 & 60.1 & 72.1 & 52.1 & 56.5 \\
\hline $\mathrm{TiO}_{2}$ & 0.21 & 0.42 & 0.28 & 0.30 & 0.23 & 0.31 & 0.21 & 0.27 \\
\hline $\mathrm{Al}_{2} \mathrm{O}_{3}$ & 12.25 & 17.62 & 12.52 & 13.46 & 11.79 & 12.91 & 9.44 & 12.38 \\
\hline $\mathrm{Fe}_{2} \mathrm{O}_{3}^{\top}$ & 9.62 & 5.32 & 2.94 & 14.61 & 7.94 & 4.92 & 8.87 & 8.17 \\
\hline $\mathrm{MnO}$ & 0.19 & 0.09 & 0.05 & 0.22 & 0.18 & 0.09 & 0.18 & 0.13 \\
\hline $\mathrm{MgO}$ & 11.37 & 1.75 & 0.86 & 8.52 & 8.75 & 1.24 & 15.05 & 9.74 \\
\hline $\mathrm{CaO}$ & 10.34 & 3.71 & 1.91 & 9.80 & 10.11 & 3.14 & 12.53 & 10.06 \\
\hline $\mathrm{Na}_{2} \mathrm{O}$ & 2.38 & 4.40 & 3.40 & 2.63 & 0.68 & 4.59 & 1.29 & 2.56 \\
\hline $\mathrm{K}_{2} \mathrm{O}$ & 0.16 & 2.03 & 1.97 & 0.72 & 0.20 & 0.64 & 0.29 & 0.13 \\
\hline $\mathrm{P}_{2} \mathrm{O}_{5}$ & 0.03 & 0.11 & 0.07 & 0.07 & 0.04 & 0.07 & 0.04 & 0.04 \\
\hline $\mathrm{Ni}$ & 191 & 3.7 & 3.4 & 39 & 105 & 3.3 & 386 & 128 \\
\hline $\mathrm{Cr}$ & 936 & 7.8 & 18 & 109 & 356 & 13 & 1521 & 627 \\
\hline $\mathrm{Zr}$ & 22 & 77 & 56 & 26 & 24 & 45 & 19 & 23 \\
\hline$Y$ & 9.6 & 23 & 18 & 13 & 7.7 & 13 & 7.6 & 8.3 \\
\hline $\mathrm{Nb}$ & 1.2 & 1.8 & 1.4 & - & 1.0 & 0.9 & - & - \\
\hline $\mathrm{Rb}$ & 3.3 & 43 & $36 \dagger$ & 15 & 5.4 & 17 & 3.4 & 0.4 \\
\hline $\mathrm{Sr}$ & 71 & 211 & $67 \dagger$ & 114 & 51 & 845 & 48 & 91 \\
\hline $\mathrm{Ba}$ & 17 & 143 & 167 & 36 & 30 & 92 & 14 & 20 \\
\hline $\mathrm{N} \mathrm{d} \dagger$ & 2.13 & 6.9 & 5.3 & 7.7 & 1.36 & 3.18 & 1.25 & 1.72 \\
\hline Smt & 0.77 & 2.27 & 1.73 & 2.48 & 0.50 & 1.08 & 0.48 & 0.60 \\
\hline $\mathrm{Pb} \dagger$ & 1.21 & 5.4 & 1.19 & 5.5 & 1.53 & 3.6 & - & - \\
\hline $\mathrm{K} / \mathrm{R} \mathrm{b}$ & 400 & 390 & 450 & 400 & 310 & 310 & 710 & 2700 \\
\hline $\mathrm{Sr} / \mathrm{Nd}$ & 33.3 & 30.6 & 12.6 & 14.8 & 37.5 & 266 & 38.4 & 52.9 \\
\hline${ }^{87} \mathrm{Sr} /{ }^{86} \mathrm{Sr}$ & 0.70516 & 0.70544 & 0.70676 & 0.70520 & 0.70525 & 0.70493 & 0.70561 & 0.70549 \\
\hline${ }^{87} \mathrm{Sr} /{ }^{86} \mathrm{Sr}^{\mathrm{i}}$ & 0.70493 & 0.70445 & 0.70408 & 0.70457 & 0.70455 & 0.70483 & 0.70526 & 0.70547 \\
\hline${ }^{143} \mathrm{~N} \mathrm{~d} /{ }^{144} \mathrm{~N} \mathrm{~d}$ & 0.51301 & 0.51301 & 0.51299 & 0.51295 & 0.51297 & 0.51297 & 0.51300 & 0.51299 \\
\hline$\varepsilon \mathrm{N} \mathrm{d}(120)$ & +7.0 & +7.3 & +7.1 & +6.3 & +6.3 & +6.5 & +6.8 & +6.9 \\
\hline${ }^{206} \mathrm{~Pb} / 204 \mathrm{~Pb}$ & 18.187 & 18.226 & 18.345 & 18.243 & 18.283 & 18.299 & 18.168 & 18.113 \\
\hline${ }^{207} \mathrm{~Pb} /{ }^{204} \mathrm{~Pb}$ & 15.518 & 15.536 & 15.552 & 15.540 & 15.569 & 15.535 & 15.524 & 15.520 \\
\hline${ }^{208} \mathrm{~Pb} /{ }^{204} \mathrm{~Pb}$ & 38.113 & 38.199 & 38.340 & 38.224 & 38.315 & 38.187 & 38.124 & 38.103 \\
\hline$\Delta^{207} \mathrm{~Pb} \neq$ & 5.6 & 6.9 & 7.2 & 7.1 & 9.6 & 6.0 & 6.4 & 6.6 \\
\hline$\Delta^{208} \mathrm{~Pb} \neq$ & 50 & 54 & 53 & 54 & 58 & 44 & 53 & 58 \\
\hline
\end{tabular}

*M ajor element totals normalized to $100 \%$, anhydrous.

$\dagger$ A nalysis by isotope dilution.

${ }^{87} \mathrm{Sr}^{26} \mathrm{Sr}_{\mathrm{i}}, \varepsilon \mathrm{Nd}(120)$ calculated using $\mathrm{t}=120 \mathrm{M}$ a and $\mathrm{Rb} / \mathrm{Sr}$, Sm/N d listed above.

$\ddagger D$ eviations from $\mathrm{N}$ orthern $\mathrm{H}$ emisphere R eference Line ( $\mathrm{H}$ art 1984).

metamorphism greatly affects $\mathrm{Sr}$, but not $\mathrm{Nd}$ or $\mathrm{Pb}$ isotopic compositions. If so, the Chalt before being metamorphosed may have had as restricted a range of $\mathrm{Sr}$ isotopic compositions as it now has $\mathrm{N} \mathrm{d}$ and $\mathrm{Pb}$ isotopic compositions. The petrologic diversity of the Chalt Volcanics can be explained by a fractional crystallization process from a parental magma similar to the Chalt boninites or basalts. $\mathrm{Nd}$ and $\mathrm{Pb}$ isotopic homogeneity for the large range of $\mathrm{SiO}_{2}$ contents in Chalt Volcanics supports this model, although this requires that the range in $\mathrm{Sr}$ isotopic composition reflects alteration. A Iternatively, the isotopic data are consistent with a model of anatexis whereby Chalt boninites or basalts were melted to generate felsic lavas. It is also noteworthy that the $\mathrm{Sr}$ and $\mathrm{N}$ d isotopic composition of the $102 \pm 12 \mathrm{M}$ a M atum D as tonalite (Petterson \& W indley 1985), which crops out along the Hunza River in the belt of Chalt Volcanics, has $\mathrm{Sr}$ and $\mathrm{Nd}$ isotopic compositions that indicate close petrogenetic affinities with the Chalt (Fig. 3; Petterson et al. 1993).

The range of ${ }^{87} \mathrm{Sr} /{ }^{86} \mathrm{Sr}_{\mathrm{i}}$ for igneous rocks of the intra-oceanic K ohistan arc $(0.7036-0.7056$; mean $=0.7043)$ is similar to that for initial ratios for correlative units from Ladakh, including the Dras Volcanics (c. 0.7035 ), $\mathrm{K}$ argil mafic cumulates (0.704-0.7053; Dietrich et al. 1983), and Ladakh intrusives (0.7034-0.7048; $\mathrm{H}$ onegger et al. 1982).

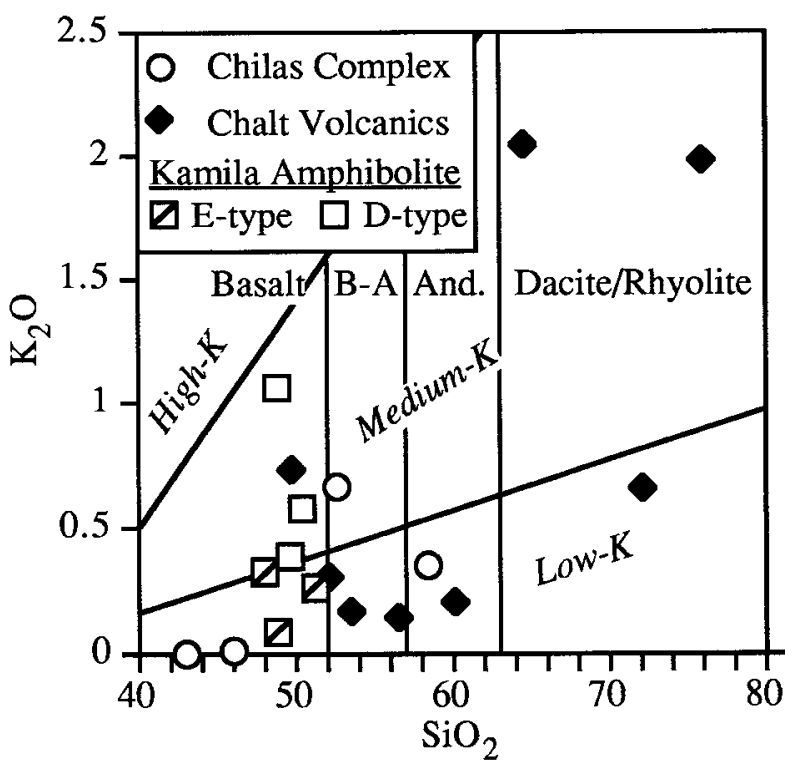

Fig. 2. Potassium-silica diagram for $K$ ohistan samples. Field boundaries are from L eM aitre (1989). B-A, basaltic andesite; And, andesite. 


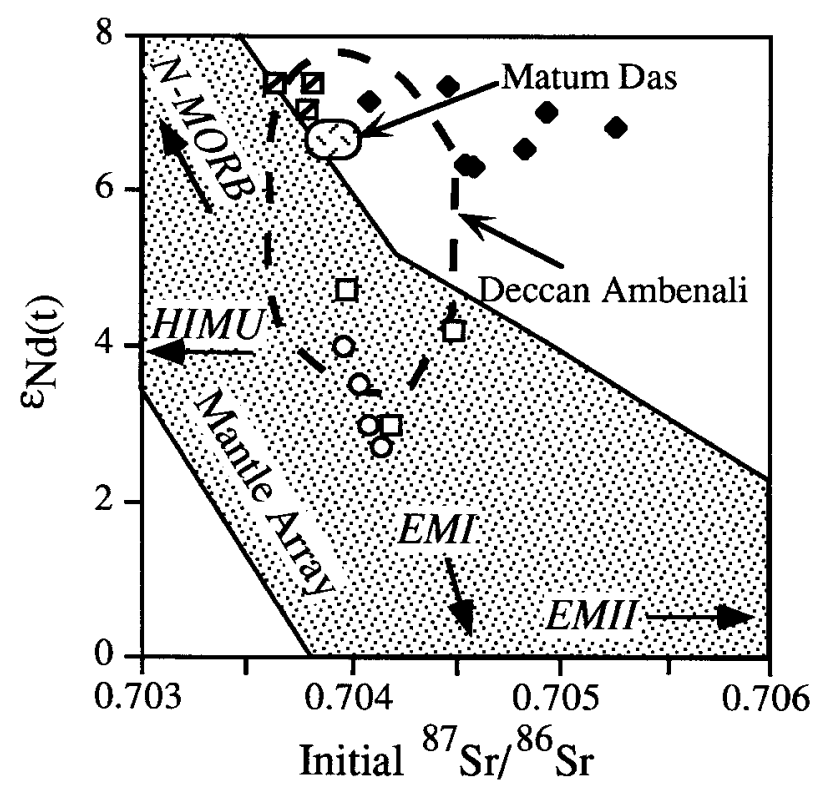

Fig. 3. $\mathrm{Sr}-\mathrm{N} d$ isotopic compositions of $\mathrm{K}$ ohistan samples. Symbols for Chalt Volcanics, Chilas Complex, and K amila E-type and $D$-type amphibolites are the same as shown in Fig. 2. Isotopic composition of $102 \mathrm{M}$ a $\mathrm{M}$ atum $\mathrm{D}$ as tonalite is from Petterson et al. (1993). A pproximate location of modern mantle array is shown for sake of comparison, along with vectors pointing towards 4 mantle reservoirs (N-M ORB, HIM U, EM I, and EM II; H art 1988). I sotopic composition of A mbenalli basalts of the D eccan Traps, India, is from Lightfoot et al. (1990).

\section{D iscussion}

The data presented here allow us to address three questions about the K ohistan intra-oceanic arc system. These are: (1) polarity of the intra-oceanic Kohistan arc; (2) nature of the source region of $\mathrm{K}$ ohistan arc magmas; (3) palaeogeographic setting of the $\mathrm{K}$ ohistan intra-oceanic arc. These items are discussed further below.

\section{Polarity of the intra-oceanic K ohistan arc}

The intra-oceanic K ohistan-Ladakh arc formed over a subduction zone which dipped beneath it either to the south or to the north. From the time it was first recognized as an intraoceanic arc complex (Tahirkheli et al. 1979), investigators have preferred the interpretation that the dip was to the north (Pudsey 1986; Petterson \& Windley 1991; R obertson \& $D$ egnan 1994). We are not convinced by the evidence for a northerly dip direction for the K ohistan subduction zone prior to collision with the $\mathrm{K}$ arakorum. R egardless of the orientation of the subduction zone beneath K ohistan, another northdipping subduction zone beneath $\mathrm{K}$ arakorum is required to generate c. $95 \mathrm{Ma}$ granodioritic rocks of the Karakorum batholith (Le Fort et al. 1983). Collision between K ohistan and $\mathrm{K}$ arakorum to form the Shyok Suture is constrained to have occurred sometime in the early Late Cretaceous, 85-102 M a ago (Treloar et al. 1989). Pudsey (1986) argued that this suture represented a collapsed back-arc basin, in part to accommodate the lack of evidence in the suture melange for subduction of a large oceanic tract.

Our understanding of the distribution of igneous rocks and their trace element and isotopic compositions in Kohistan

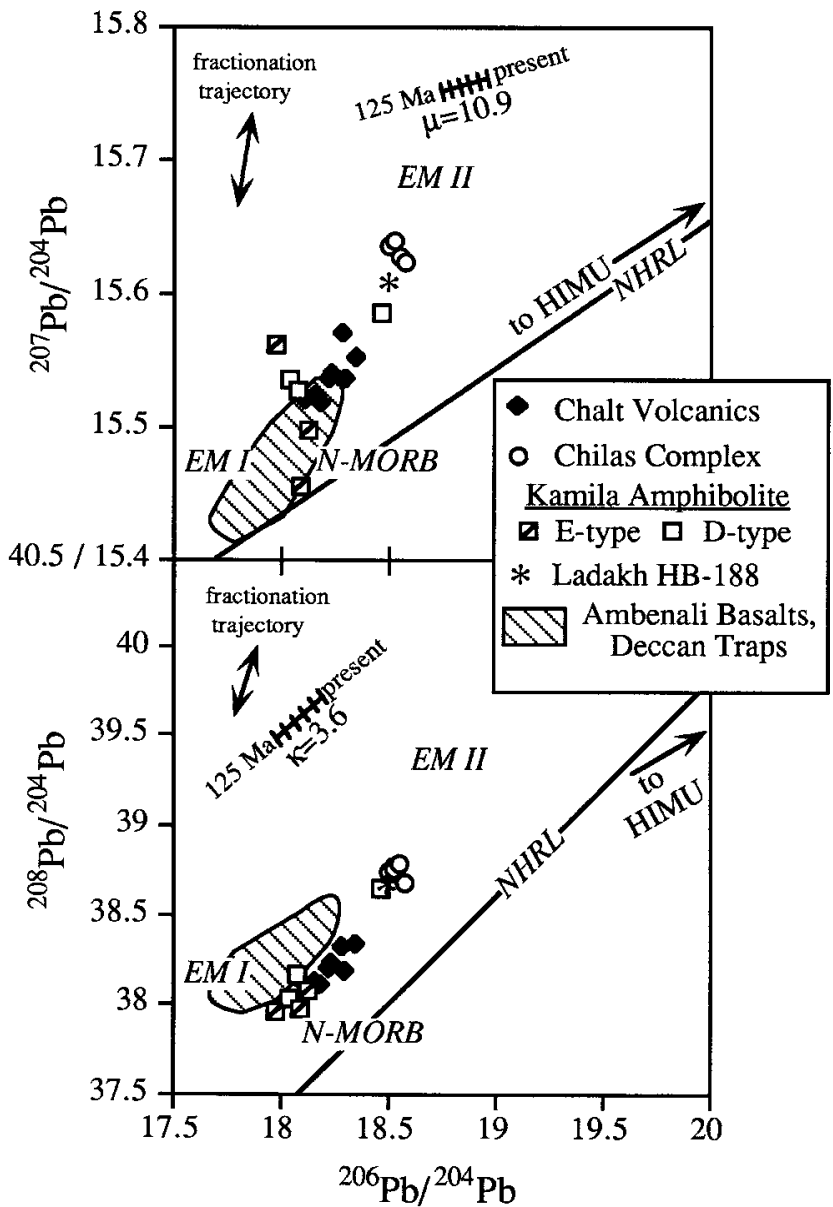

Fig. 4. $\mathrm{Pb}$ isotopic compositions of $\mathrm{K}$ ohistan igneous rocks. Line labelled ' $\mathrm{NHRL}$ ' is the northern hemisphere reference line of $\mathrm{H}$ art (1984). A pproximate positions of model mantle reservoirs EM I, EMII, and N-M OR B are shown; HIM U lies off the diagram to the right (H art 1988). A sterisk denotes isotopic composition of $\mathrm{Pb}$ in $\mathrm{K}$-feldspar from a $101 \pm 2 \mathrm{M}$ a granodiorite from L adakh (Schärer et al. 1984). I sotopic composition of A mbenali basalts, D eccan Traps, India, is from Lightfoot et al. (1990). A lso shown are trajectories of isotopic composition corrected for radiogenic growth back to $125 \mathrm{M}$ a (25 million year steps), assuming $\mu$ $\left({ }^{238} \mathrm{U} /{ }^{204} \mathrm{~Pb}\right)=10.9$ and $\kappa\left({ }^{232} \mathrm{Th} /{ }^{238} \mathrm{U}\right)=3.6$. This is intended to illustrate the magnitude and the general direction of isotopic changes that may have occurred in these samples since these lavas were erupted in the Cretaceous. A Iso shown are vectors appropriate for fractionation trajectories due to thermal fractionation during analysis; the length of the vector corresponds to $\pm 0.15 \% / a m u$.

presents another perspective for constraining subduction polarity of the intra-oceanic K ohistan arc. We conclude that the chemical and isotopic composition of K ohistan igneous rocks, particularly the Chalt and $\mathrm{K}$ amila volcanic sequences, formed over a south-dipping subduction zone. We appreciate that our interpretation is not exclusive; for example, Treloar et al. (1996) infer that the $\mathrm{K}$ amila provides substrate to $\mathrm{C}$ halt cover. However, we find that the geochemical and isotopic data are more consistent with $\mathrm{K}$ ohistan sequences reflecting changes across an approximately contemporaneous arc system. There are two lines of evidence to support this. (1) The Chalt Volcanics (especially their boninitic component) are interpreted to have formed in a forearc setting (Petterson \& Windley 1991). There are several models for why boninites 
form in forearcs, including subduction initiation (Stern \& Bloomer 1992; Bloomer et al. 1995), spreading-centre subduction (Crawford et al. 1989; Pearce et al. 1992), and interaction of the elevated thermal regime associated with a back-arc basin spreading center superimposed on the high water flux of a forearc (F alloon \& Crawford 1991). D iscussion continues regarding which of these models is most appropriate, but the consensus that boninites form in fore-arc settings remains. The interbedded submarine boninites, low-Ti tholeiites, and felsic rocks of the $C$ halt $V$ olcanics are reminiscent of the I zu-Bonin-M ariana forearc, as is the rapid transition from volcanism to carbonate-dominated pelagic and hemipelagic sedimentation represented by the Chalt-Y asin succession (Bloomer et al. 1995). (2) The M OR B-like affinities of K amila $\mathrm{E}$-type metavolcanic amphibolites and their intercalation with D -type amphibolites which have a strong subduction component is most consistent with the interpretation that these formed in a back-arc basin. MORB-like magmas are only found at convergent margins in a back-arc basin setting, and sequences containing alternating or interfingering M OR B - and arc-tholeiites are characteristic of modern back-arc basins such as the M ariana Trough and Lau Basin (Wood et al. 1981; H awkins 1995; G ribble et al. 1996).

The inference that the 'subduction component' becomes less important from the $\mathrm{C}$ halt $\mathrm{V}$ olcanics in the north to the $\mathrm{K}$ amila A mphibolites in the south is also supported by an overall increase in the incompatible HFS elements $\mathrm{Ti}$ and $\mathrm{Zr}$ in the same direction. A bundances of HFS elements in an intraoceanic convergent margin increase from the forearc to the back-arc, which reflects an overall decrease in the degree of melting or degree of source region depletion that gives a clear facing direction for the arc (Taylor et al. 1992). The HFSE evidence for $\mathrm{K}$ ohistan is very clear; considering only rocks with $48-59 \% \mathrm{SiO}_{2}$, the Chalt Volcanics contain $\leq 0.3 \% \mathrm{TiO}_{2}$ and $<30 \mathrm{ppm} \mathrm{Zr}$; Chilas Complex samples contain 0.84 and $1.24 \% \mathrm{TiO}_{2}$ and 71-133 ppm Zr; K amila samples contain as much as $2.25 \% \mathrm{TiO}_{2}$ and $149 \mathrm{ppm} \mathrm{Zr}$. These relationships are graphically presented in $\mathrm{Fig}$. 5 , by which result the intraoceanic Kohistan arc faced northwards above a S-dipping subduction zone.

The tectonic model that we prefer is shown in Fig. 6 . F igure 6a shows the intra-oceanic phase and features an ocean basin ( $\mathrm{N}$ eotethys) between $\mathrm{K}$ arakorum and Kohistan. This ocean closed as a result of two subduction zones, one dipping north beneath $\mathrm{K}$ arakorum and the other dipping south beneath Kohistan. This tectonic situation has a modern analogue in the M olucca Sea, south of the Philippines. The $M$ olucca Sea is closing as a result of west-dipping subduction beneath the Sangihe Arc to the west and east-dipping subduction beneath the $\mathrm{H}$ almahera A rc to the east ( $\mathrm{H}$ amilton 1978; M oore et al. 1981).

There is no evidence for a hiatus in India's northward motion during the $L$ ate $C$ retaceous, and continuous northward motion requires a new subduction zone to form immediately after K ohistan and K arakorum collided. This new subduction zone dipped north on the south side of $K$ ohistan. This reversal of subduction polarity beneath $\mathrm{K}$ ohistan during the $\mathrm{L}$ ate Cretaceous is analogous to the situation inferred for the Solomon Arc during the Late Tertiary (Cooper \& Taylor 1985). Thickened crust of the Ontong J ava Plateau arrived at the $\mathrm{V}$ itiaz Trench on the north side of the Solomon A rc during the $M$ iocene. This stopped south-dipping subduction and led to the formation of a new, north-dipping subduction zone southwest of the Solomons.
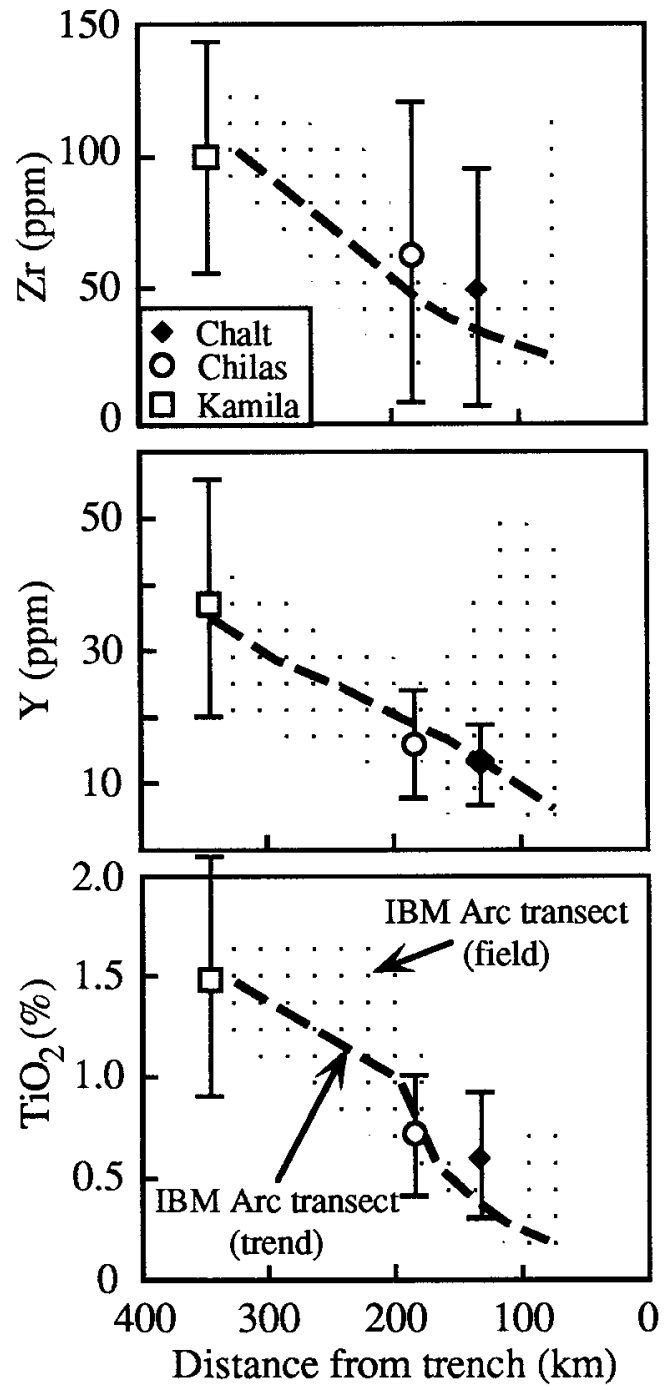

Fig. 5. A bundances of high field strength elements $Z r, Y$, and $T i$ for $K$ ohistan intraoceanic phase igneous rocks, compared with data for transects across the Izu-Bonin-M ariana (IBM) intra-oceanic arc system, reported by Taylor et al. (1992). Stippled field encompasses all IBM data for samples, filtered for $3.5 \%<\mathrm{M}$ gO $<15 \%$; dashed line is our estimate of the 'best fit' trend of the data. IBM A rc system data indicate increasing HFSE concentrations with distance from the trench. D ata for K ohistan samples includes mean \pm 1 standard deviation. Positions of Chalt, Chilas, and $\mathrm{K}$ amila are shown to make the point that $\mathrm{K}$ ohistan HFSE data are most consistent with the sequence of units having the following order of increasing distance from the trench: Chalt, Chilas, and K amila. This is consistent with a model for the formation of the $\mathrm{K}$ ohistan intra-oceanic arc system over a south-dipping subduction zone. K ohistan data sources follow: Chalt $(n=41)$, Petterson $\&$ W indley (1985, 1991), L uff \& Windley (unpublished); Chilas $(n=40), K$ han et al. (1989); $K$ han (unpublished); $K$ amila $(n=37), K$ han (unpublished).

Our model satisfies all tectonic constraints, including: (1) India began moving north during the magnetic quiet zone, at approximately $120 \mathrm{M}$ a, and continued to move rapidly north until collision with $\mathrm{A}$ sia about $50 \mathrm{M}$ a ago (Patriat $\&$ A chache 1984). The northward movement of India reflects the development of subduction zones to the north at about $120 \mathrm{Ma}$ (Scotese et al. 1988). (2) N orth-dipping subduction is required 


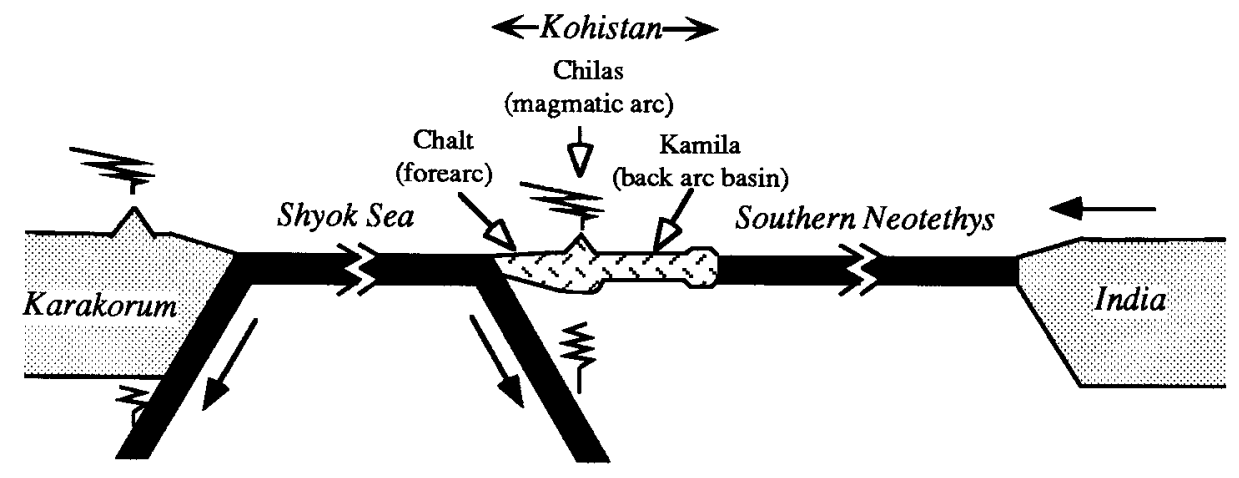

A) Kohistan - Intra-oceanic Phase - ca. $100 \mathrm{Ma}$

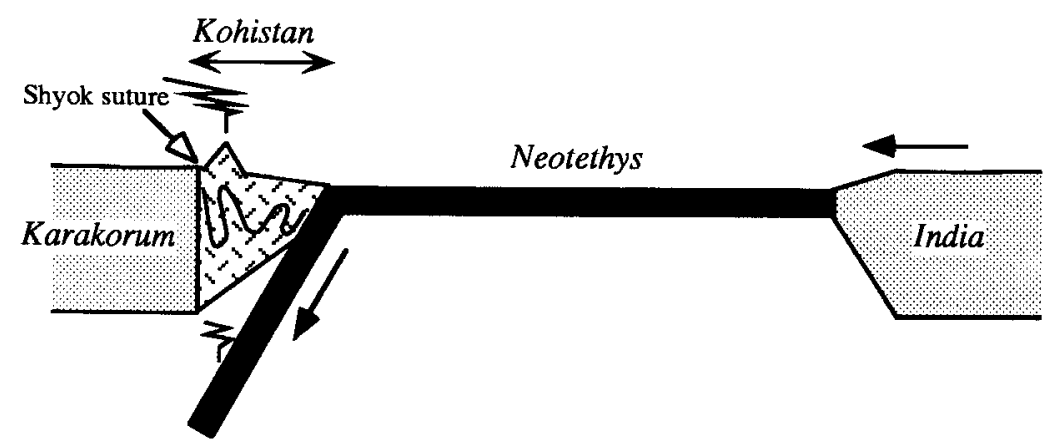

B) Kohistan - Andean Margin Phase - ca.70 Ma
Fig. 6. Tectonic model for evolution of the K ohistan arc. (a) Intraoceanic phase. India drifts northwards (left) due to closing of an ocean basin between $\mathrm{K}$ arakorum and $\mathrm{K}$ ohistan. $\mathrm{K}$ ohistan is on the same plate as India. N ote positions of Chalt Volcanics, Chilas Complex, and $\mathrm{K}$ amila A mphibolites. (b) A ndean phase. Kohistan has collided with $\mathrm{K}$ arakorum and a new, northward-dipping subduction zone has formed on the south side of accreted K ohistan. India continues to move north. beneath $\mathrm{K}$ arakorum to generate the $\mathrm{K}$ arakorum batholith (Searle 1991). (3) F ollowing the formation of the Shyok suture, the subduction zone associated with the northward motion of India dipped north on the south side of accreted Kohistan. This explanation is also consistent with the presence of S-dipping structures in northern Kohistan (Coward et al. 1982), which may have formed in association with a S-dipping subduction zone.

$\mathrm{N}$ ature of the source region of K ohistan intra-oceanic arc magmas

One of the important controversies surrounding convergent margin magma-genesis concerns the relative contributions provided by mantle as opposed to subducted crust and sediments. U nderstanding this chemical budget is important not only for understanding arc magma-genesis, but also for understanding a wide range of other first-order questions about the earth, including whether or not the Earth's mantle and crust are still differentiating, whether the continents are growing or shrinking, and how the sources of hot-spot mantle formed. It is widely acknowledged that a hydrous subduction zone environment may be responsible for fractionating elements that are not fractionated in anhydrous magmagenetic environments such as hot spots or mid-ocean ridges. The most spectacular of these incompatible element fractionations in arcs is the relatively high abundance of fluid-mobile alkali metals and alkaline earths ( $\mathrm{K}, \mathrm{R} \mathrm{b}, \mathrm{Ba}, \mathrm{Sr}$ ) relative to the abundance of less mobile high field strength elements (e.g., Ti, Zr, Y, N b, Ta). $\mathrm{H}$ aving acknowledged these fractionations and the fact that some elements are clearly derived from subducted components such as ${ }^{10} \mathrm{Be}$ ( $\mathrm{M}$ orris et al. 1990), the question remains as to the relative importance of contributions of other incompatible elements that are extracted from the mantle compared to those that are recycled from subducted crust and sediments.

We argue that the distinctive isotopic signature of Indian Ocean mantle is readily recognized in the composition of Kohistan igneous rocks, and that this signature overwhelms any signature from subducted sediment. $\mathrm{H}$ art (1984) recognized a zone of enriched mantle underlying equatorial oceanic regions which he called DUPAL. DUPAL mantle generates lavas with distinctive isotopic characteristics, including relatively low $\varepsilon \mathrm{N} \mathrm{d}$ and ${ }^{206} \mathrm{~Pb} /{ }^{204} \mathrm{~Pb}$, and relatively high ${ }^{87} \mathrm{Sr} /{ }^{86} \mathrm{Sr}$ and $\Delta 8 / 4$. Regions underlain by DUPAL mantle are presently far to the south of Kohistan, but DUPAL isotopic characteristics are readily identified in all igneous rocks from the intraoceanic phase of the Kohistan $\operatorname{arc~(Fig.~7).~}$

A nother perspective is gained from comparison of $\mathrm{K}$ ohistan igneous rocks with D eccan traps. The D eccan Traps are flood basalts that erupted about $65 \mathrm{M}$ a when India passed over the Reunion hotspot. M ost of the Deccan basalts have been significantly contaminated by continental lithosphere, but the A mbenali unit in the upper part of the sequence is thought to manifest predominantly asthenospheric isotopic compositions (Lightfoot \& H awkesworth 1988; Peng \& M ahoney 1995). The A mbenali basalts formed about $3500 \mathrm{~km}$ south of their present position and thus represent the composition of the asthenosphere beneath the subequatorial Indian Ocean basin at the end of Cretaceous time. They show DUPAL isotopic characteristics, especially high $\Delta 8 / 4$, and constitute an appropriate data set that can be used to examine the potential mantle controls on the isotopic composition of Kohistan igneous rocks. 

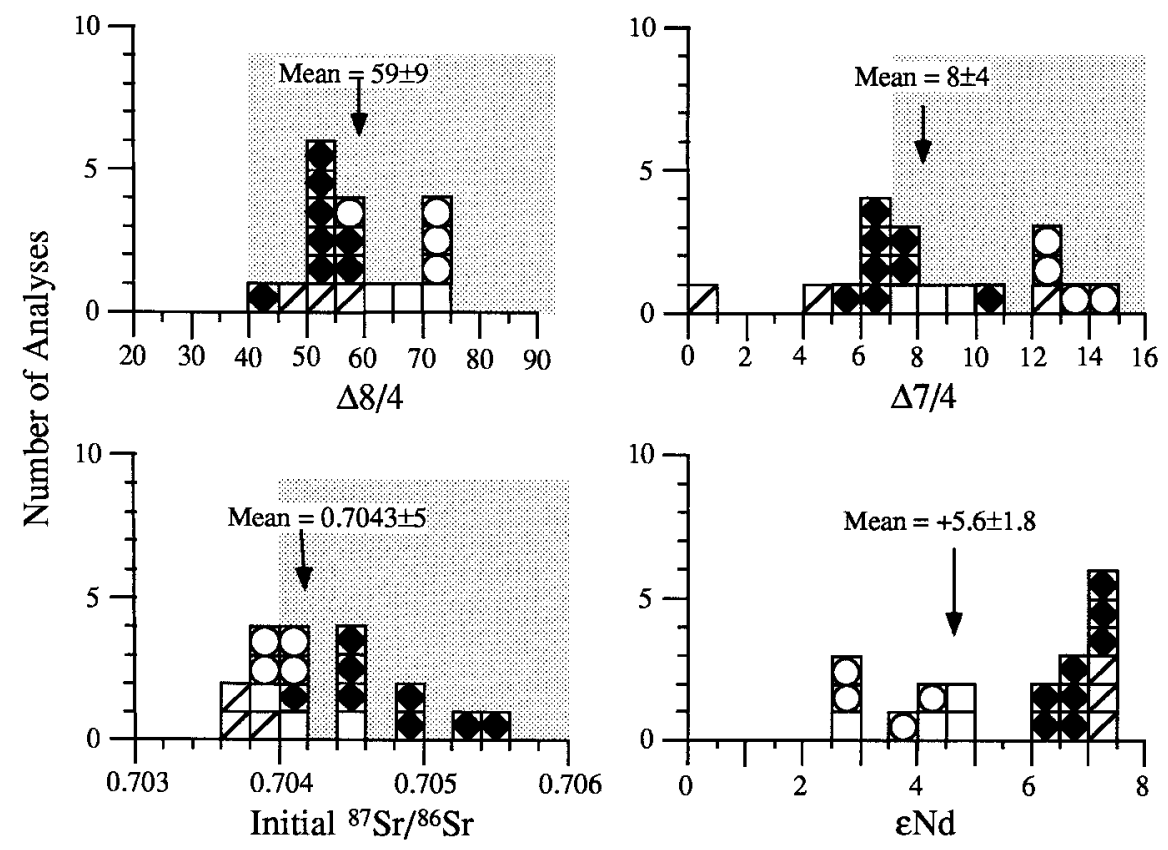

\begin{tabular}{|llc|}
\hline Chalt Volcanics & Kamila Amphibolites & DUPAL \\
D Chilas Complex & $\square$ E-type $\square$ D-type & Isotopic Characteristics \\
\hline
\end{tabular}

Fig. 7. Histogram of initial isotopic composition of $\mathrm{Sr}$ and $\mathrm{N} \mathrm{d}$ and measured $\mathrm{Pb}$ istopic compositions reported using $\Delta$ notation of $\mathrm{H}$ art (1984). M eans ( \pm 1 std. dev.) are for the entire $K$ ohistan suite. Stippled field labelled 'DUPAL I sotopic Characteristics' are taken from $\mathrm{H}$ art (1984) for Sr and Pb; DUPAL N d isotopic characteristics are not given by $\mathrm{H}$ art (1984).
Six samples of A mbenali basalts analysed by $L$ ightfoot et al. (1990) have $\varepsilon \mathrm{N} \mathrm{d}$ of +4.3 to +7.5 and ${ }^{87} \mathrm{Sr} /{ }^{86} \mathrm{Sr}$ of 0.7039 0.7046 , very similar to the range of $\mathrm{K}$ ohistan igneous rocks $\left(\varepsilon \mathrm{N} \mathrm{d}=+2.8\right.$ to +7.4 and $\left.{ }^{87} \mathrm{Sr} /{ }^{86} \mathrm{Sr}=0.7036-0.7055\right)$. The similarity of the $\mathrm{Sr}-\mathrm{Nd}$ isotopic systematics of $\mathrm{K}$ ohistan and A mbenali igneous rocks is shown in Fig. 3. Differences between the $\mathrm{Sr}$ and $\mathrm{N} d$ isotopic systematics of $\mathrm{K}$ ohistan igneous rocks and Ambenali basalts consist of extension of the $\mathrm{K}$ ohistan suite to slightly lower $\varepsilon \mathrm{Nd}$ that nevertheless lie within the mantle array, and the higher ${ }^{87} \mathrm{Sr} /{ }^{86} \mathrm{Sr}$ of the Chalt Volcanics. The $\mathrm{Pb}$ isotopic compositions of $\mathrm{K}$ ohistan igneous rocks are also similar to those of A mbenali basalts, as shown on $\mathrm{Fig}$. 4. The A mbenali basalts have a somewhat lower range

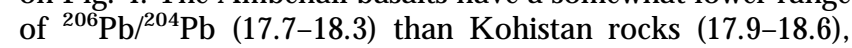
but are similar in lying above the northern hemisphere reference line ( $N H R L$ ) in similarly distinctive fashions. On a plot of ${ }^{207} \mathrm{~Pb} /{ }^{204} \mathrm{~Pb}$ v. ${ }^{206} \mathrm{~Pb} /{ }^{204} \mathrm{~Pb}$ ( $\mathrm{Fig}$. 4), both define a trend that obliquely intersects N HRL at ${ }^{206} \mathrm{~Pb} /{ }^{204} \mathrm{~Pb} \approx 17.6$ and extends towards the EMII reservoir. On a plot of ${ }^{208} \mathrm{~Pb} /{ }^{204} \mathrm{~Pb} \mathrm{~V}$. ${ }^{206} \mathrm{~Pb} / 204 \mathrm{~Pb}$, both define a trend which lies above and parallel to N HRL. The Pb isotopic characteristics for both $\mathrm{K}$ ohistan and Ambenali are consistent with mixing between mantle reservoirs $E M I$ and EMII. Intriguingly, evidence of such mixing cannot be inferred from $\mathrm{Sr}-\mathrm{N}$ d systematics (F ig. 3).

\section{Palaeogeographic setting of the K ohistan intra-oceanic arc}

Our inferences regarding polarity of the intra-oceanic $K$ ohistan arc and its formation in an oceanic real $m$ dominated by DUPAL mantle sources lead us to propose a palaeogeographic model for Early Cretaceous time (Fig. 8). It shows K ohistan lying within the DUPAL region, about $3000 \mathrm{~km}$ south of the Karakorum. The Shyok Sea, that part of $\mathrm{N}$ eotethys north of $\mathrm{K}$ ohistan, lies between $\mathrm{K}$ ohistan and
$\mathrm{K}$ arakorum. India and $\mathrm{K}$ arakorum move northwards together until $\mathrm{K}$ ohistan collides with $\mathrm{K}$ arakorum, when a new, northdipping subduction zone is constructed on the south flank of $\mathrm{K}$ ohistan. The development of this new subduction zone may be manifested by the first stages in the development of the Oman subduction zone (obduction of the Semail ophiolite), about 90-95 M a (Lippard et al. 1986).

This model is subject to a number of uncertainties which affect the size of the seaway that lay between $\mathrm{K}$ ohistan and southern A sia. F irst of all, the location of the southern margin of $A$ sia at this time is controversial. F or example, we present the configuration of Scotese et al. (1988) which places it about $15^{\circ} \mathrm{N}$, but Searle (1991) places it closer to $10^{\circ} \mathrm{N}$. Secondly, the location of $\mathrm{K}$ ohistan is not highly constrained. It must lie between India and A sia, and we infer from the isotopic data that it lay in the DU PA L realm, but where precisely? We have also assumed that the surface projection and location of the DUPA L anomaly has not changed significantly in the past 100 million years. These uncertainties indicate that we cannot use the isotopic data to quantitatively reconstruct K ohistan's paleolatitude in Cretaceous time; nevertheless it should be noted that the paleomagnetic study of $Y$ oshida et al. (1996) place K ohistan slightly south of the Equator about $100 \mathrm{M} \mathrm{a}$ ago.

A nother way to look at these uncertainties is to try to minimize the size of the Shyok Sea. If we accept Searle's (1991) position for southern $\mathrm{A}$ sia at $10^{\circ} \mathrm{N}$ and a location for $\mathrm{K}$ ohistan closer to the northern limits of the DUPA L anomaly, perhaps along the equator, the Shyok Seaway shrinks in width to perhaps $1000 \mathrm{~km}$. There is nothing in our data that precludes alternate configurations such as this.

\section{Conclusions}

$\mathrm{G}$ eochemical and isotopic data reported here are most consistent with the model that the K ohistan intra-oceanic arc faced 


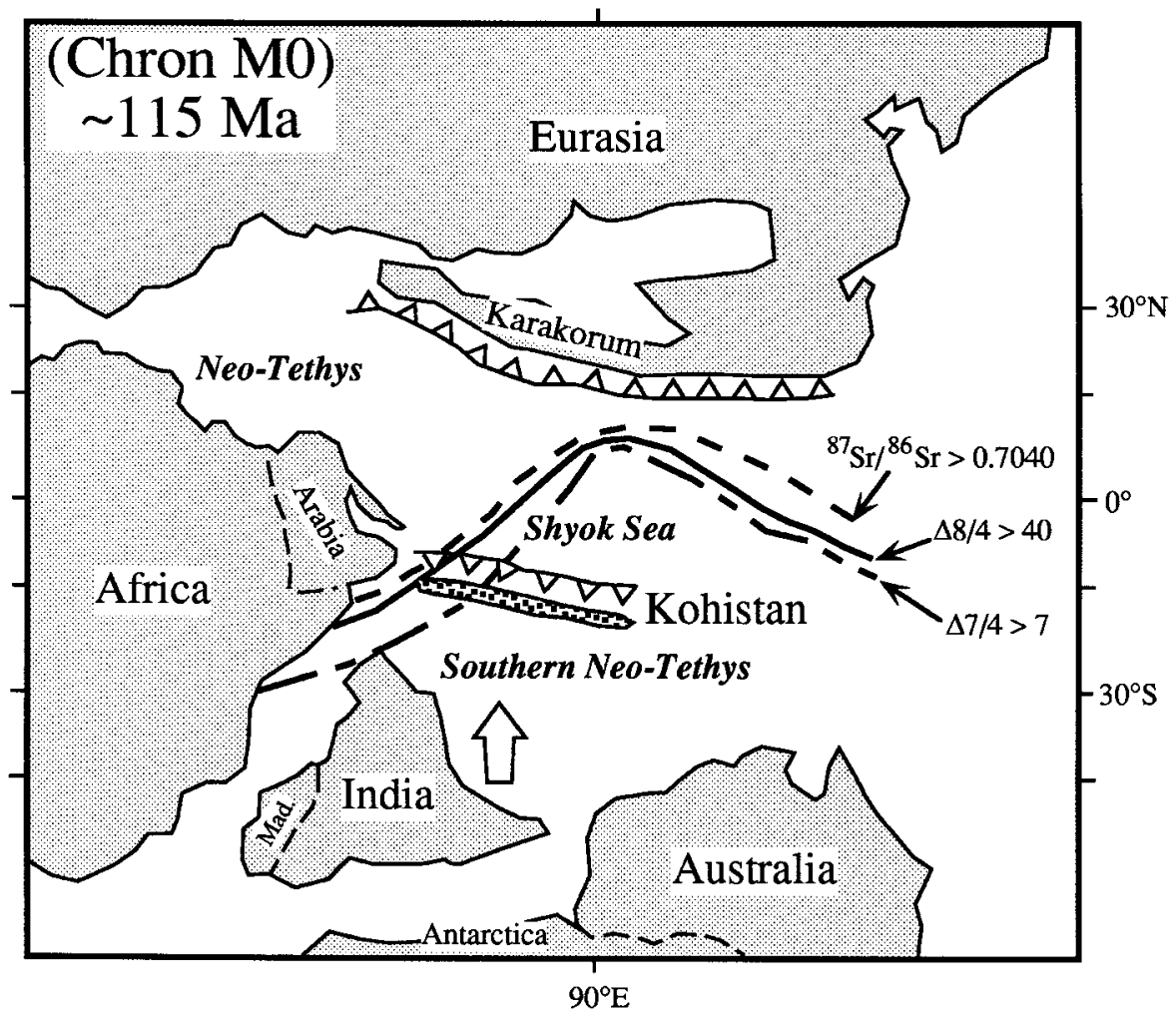

Fig. 8. Suggested palaeogeographic setting of the Kohistan arc during A ptian-A lbian times. Positions of continents is generalized after Scotese et al. (1988, fig. 10), although the precise palaeolatitude of A sia is controversial. Present northern limits of DU PA L anomaly (located by ${ }^{87} \mathrm{Sr} /{ }^{86} \mathrm{Sr}>0.7040$, $\Delta 7 / 4>7$ and $\Delta 8 / 4>40$ ) are from $\mathrm{H}$ art (1984). Position of trenches and convergent plate margins are shown, with 'teeth' on the overriding plate. N ote that during this time, Kohistan and India move northwards on the same plate. Compare this figure with Fig. $6 a$.

north, with forearc crust in the north (Chalt volcanics) and backarc crust in the south ( $\mathrm{K}$ amila amphibolites). The isotopic data indicate $\mathrm{K}$ ohistan igneous rocks formed by melting of a mantle source with a strong DUPA L isotopic signature. Such mantle sources exist in the oceanic realm far to the south of the present tectonic setting of K ohistan.

M.A.K. thanks the US Fullbright Program for support during 1993-1994. I sotopic studies at UTD were supported by NSF grant OCE-9302162. Field work was supported by NERC grant GR 3/4242. M.A.K. acknowledges support for field work NSRDB project Esc. 24 and field assistance by $M$. A hmed $K$ han and $M$. S. Q azi. B. L. W eaver arranged for XRF analyses at Norman. M. Q. Jan and B. L. Weaver provided Chilas analyses and samples for isotope analyses. We appreciate the thoughtful comments of $\mathrm{S}$. Inger and $\mathrm{P}$. Treloar. Thanks also to S. D. K ahn for reducing the data used to generate Fig. 5 .

\section{A ppendix: sample localities and descriptions}

A $83 \quad N$ iat $G$ ah, south of L umar. F oliated, fine-grained metavolcanic amphibolite, otherwise homogeneous.

A $86 \quad \mathrm{~N}$ iat $\mathrm{G}$ ah, north of $L$ umar. F ine-grained, metavolcanic amphibolite.

A $93 \quad \mathrm{~N}$ iat $\mathrm{G}$ ah, $100 \mathrm{~m}$ north of the $\mathrm{N}$ iagran village (part of $\mathrm{N}$ iat metavolcanics). D ark, hornblende-rich metavolcanic amphibolite

A 119 Buto Gah, just north of village Sumal. Porphyritic meta-andesite, with relict pillow structure.

A 121 Buto $\mathrm{G}$ ah, $200 \mathrm{~m}$ south of village Chakhar. $M$ eta-andesite, similar to A 119.

A 125 Buto $G$ ah, north of Chakkar. N iat-type metavolcanics

IK 1007 Eastern part of Thuly ultramafic body. M edium-grained noritic troctolite: PLAG-OPX-CPX-HB-SP. OL consumed in reaction to form $\mathrm{OPX}+\mathrm{HB}$
IK 1009 Thak bridge, K arakorum Highway. Peridotite dyke intruding the main ultramafic body. OL-HB-OPX-CPX-SP-CC-PLAG .

IK $101210 \mathrm{~m}$ east of bridge near Chilas. G abbronorite. $M$ edium-grained, mildly foliated. PL-OPX-CPX-BIO-(opaque oxide-H B-K F-QZ-A P).

IK $101717 \mathrm{~km}$ east of Sazin. H ypersthene quartz diorite. M edium-grained. PLA G-H B-OPX-CPX-QZ-K F-A P (titanite and zircon).

PL 28 A bout $3 \mathrm{~km}$ south of Chalt village, Hunza Valley; boninite.

PL29 A bout $3 \mathrm{~km}$ south of Chalt village, H unza Valley; andesite.

N 115 A bout $2 \mathrm{~km}$ south of Chalt village, H unza Valley; rhyolite.

N 116 A bout $2 \mathrm{~km}$ south of Chalt village, H unza Valley; basalt.

$\mathrm{N} 138$ A bout $5 \mathrm{~km}$ south of Chalt village, H unza Valley; calc-alkaline lava.

N 139 A bout $5 \mathrm{~km}$ south of Chalt village, H unza Valley; rhyolite.

N 161 A bout $6.5 \mathrm{~km}$ south of Chalt village, Hunza Valley; boninite.

IK 5803 km south of J aglot G ah, H unza Valley; boninite.

\section{R eferences}

BEARD, J.S. 1986. Characteristic mineralogy of arc-related cumulate gabbros: Implications for the tectonic setting. Geology, 14, 848-851.

Bloomer, S.H., T AYlor, B., M aCL eOd, C.J ., Stern, R .J ., F R rer, P., H AWkins, J.W. \& J oHnson, L. 1995. Early A rc Volcanism and the O phiolite Problem: A Perspective from Drilling in the Western Pacific. In: TAYLOR, B. \& $N_{\text {ATLAND, }} J$. (eds) Active $M$ argins and $M$ arginal Basins of the $W$ estern Pacific. A merican G eophysical U nion, G eophysical M onographs, 88, 1-30.

CoOPER, P.A . \& TAYLOR, B. 1985. Polarity reversal in the Solomon Islands arc. N ature, 314, 428-430.

Coward, M .P., J AN, M .Q., ReX, D., T ARney, J., Thirlwall, M \& \& W INDley, B.F. 1982. Structural evolution of a crustal section in the western H imalaya. $\mathrm{N}$ ature, 295, 22-24. 
- - , W indley, B.F ., Broughton, R .D ., L UfF, I.W., Petterson, M .G ., Pudsey, C.J., ReX, D.C. \& K HAN, M.A. 1986. Collision tectonics in the NW H imalayas. In: Coward, M .P. \& RiEs, A.C. (eds) Collision Tectonics. Geological Society, London, Special Publications, 19, 203-219.

Crawford, A.J., Falloon, T.J. \& GReEN, D.H. 1989. Classification, petrogenesis and tectonic setting of boninites. In: CRAwFord, A.J. (ed.) Boninites. Unwin Hyman, London, 1-49.

Dietrich, V.J., F RANK, W. \& H ONEGGAR, K . 1983. A J urassic-Cretaceous island arc in the Ladakh Himalayas. J ournal of Volcanology and Geothermal Research, 18, 405-433.

Falloon, T.J. \& C Crawford, A.J. 1991. The petrogenesis of high-calcium boninite lavas dredged from the northern Tonga ridge. E arth and P lanetary Science L etters, 102, 375-394.

Gribble, R.F., Stern, R.J., Bloomer, S.H., Stüben, D., O'Hearn, T. \& N Ewman, S. 1996. M OR B M antle and Subduction Components Interact to Generate Basalts in the Southern M ariana Trough Back-Arc Basin. Geochimica et Cosmochimica Acta, 60, 2153-2166.

H AmiLton, W.B. 1978. T ectonics of the Indonesian R egion. U S G eological Survey Professional Paper, $\mathbf{1 0 7 8 .}$

- - 1994. Subduction systems and magmatism. In: Smellie, J.L. (ed.) Volcanism Associated with Extension at Consuming Plate M argins. Geological Society, London, Special Publications, 81, 3-28.

$\mathrm{H}_{\mathrm{ART}}$, S.R. 1984. A large-scale isotope anomaly in the southern hemisphere mantle. $N$ ature, 309, 753-757.

- - 1988. Heterogeneous mantle domains: signatures, genesis and mixing chronologies. Earth and Planetary Science L etters, 90, 273-296.

H ARVEY, P.K. \& A TKINS, B.P. 1982. The estimation of mass absorption coefficients by Compton scattering: Extensions to the use of $R h$ $\mathrm{K} \alpha$ Compton Radiation and intensity ratios. A merican M ineralogist, 67 , 534-537.

H AwKINS, J.W. 1995. Evolution of the L au Basin-Insights from ODP L eg 135. In: TAYLOR, B. \& N ATLAND, J. (eds) Active $M$ argins and $M$ arginal Basins of the Western Pacific. American Geophysical Union, Geophysical M onographs, 88, 125-173.

H ONEGGER, K., Dietrich, V., F RANK, W., G ANSSER, A., ThÖNI, M. \& TROMMSDORFF, V. 1982. M agmatism and metamorphism in the Ladakh $\mathrm{H}$ imalayas (the Indus-T sangpo suture zone). E arth and Planetary Science L etters, 60, 253-292.

JAN, M.Q. 1988. Geochemistry of amphibolites from the southern part of K ohistan arc, N. Pakistan. M ineralogical M agazine, 52, 147-159.

- - \& HowIE, R.A. 1980. Ortho- and clinopyroxenes from the pyroxene granulites of Swat K ohistan, northern Pakistan. M ineralogical M agazine, 43, 715-726.

K han, M .A ., J AN, M .Q. \& W Eaver, B.L. 1993. Evolution of the lower arc crust in K ohistan, N. Pakistan: temporal arc magmatism through early, mature, and intra-arc rift stages. In: T ReLOAR, P.J \& \& SeARLE, M .P. (eds) H imalayan Tectonics. G eological Society, London, Special Publications, 74, 123-138.

,,---- W INDLEY, B.F., T ARNeY, J. \& ThIRLwall, M .F. 1989. The Chilas mafic-ultramafic igneous complex: the root of the $\mathrm{K}$ ohistan island arc in the Himalaya of northern Pakistan. In: M ALINCONICO, L.L. JR \& L ILLIE, R.J. (eds) Tectonics of the Western $\mathrm{H}$ imalayas. Geological Society of A merica, Special Papers, 232, 75-94.

LeF ort, P., M ichard, A., Sonet, J \& \& Zimmermann, J.L. 1983. Petrography, geochemistry, and geochronology of some samples from the K arakoram axial batholith (northern Pakistan). In: Shams, F.A. (ed.) Granites of the $\mathrm{H}$ imalayas, Karakorum, and $\mathrm{H}$ indu Kush. Institute of $\mathrm{Geology}$, Punjab U niversity, Lahore, India, 377-387.

LEM AITRE, R.W. (ed.) 1989. A Classification of Igneous Rocks and Glossary of Terms. Blackwell, London.

Lightfoot, P.C. \& H AwKesworth, C.J. 1988. Origin of Deccan Trap lavas: evidence from combined trace element and $\mathrm{Sr}-, \mathrm{N} \mathrm{d}$ - and $\mathrm{Pb}$-isotope studies. E arth and Planetary Science L etters, 91, 89-104.

- - - - , Devey, C.W., Rogers, N.W. \& V V AN Calsteren, P.W.C. 1990. Source and Differentiation of Deccan Trap Lavas: Implications of Geochemical and M ineral Chemical Variations. J ournal of Petrology, 32, $1165-1200$.

M ANTON, W.I. 1988. Separation of $\mathrm{Pb}$ from young zircons by single-bead ion exchange. Chemical Geology (I sotope Geoscience), 73, 147-152.

M ICHARD, A., Boudier, F \& \& G OFFÉ, B. 1991. Obduction versus Subduction and Collision in the Oman Case and Other Tethyan Settings. In: PETERS, T J. N icolas, A \& \& Coleman, R.G. (eds) O phiolite Genesis and Evolution of the O ceanic L ithosphere. K luwer, L ondon, 447-467.

M oore, G.F., K adarisman, D., Evans, C.A.\& Hawkins, J.W. 1981. G eology of the Talaud Islands, M olucca Sea collision zone, northeast Indonesia. J ournal of Structural Geology, 3, 467-475.
M ORRIS, J., L EemAN, W.P. \& Tera, F. 1990. The subducted component in island arc lavas: constraints from Be isotopes and B-Be systematics. N ature, 344, 31-36.

Nesbitt, R.W., M astins, H., Stolz, G.W. \& Bruce, D.R. 1976. M atrix corrections in trace element analysis by $X$-ray flourescence: an extension of the Compton scattering technique to long wavelengths. Chemical Geology, 18, 203-213.

Patriat, P. \& AChache, J. 1984. India-Eurasia collision chronology has implications for crustal shortening and driving mechanism of plates. Nature, 311, 615-621.

Pearce, J.A. 1984. Role of sub-continental lithosphere in magma genesis at active continental margins. In: H AWKesworTH, C.J. \& N ORRY, M .J. (eds) Continental Basalts and $M$ antle $X$ enoliths. Shiva, $N$ antwich, 230-249.

Pearce, J.A., VAN Der LaAn, S.R., A rCulus, R.J., M urton, B.J., I ShiI, T., PeAte, D.W. \& Parkinson, I.J. 1992. Boninite and harzburgite from Leg 125 (Bonin-M ariana forearc): A case study of magma genesis during the initial stages of subduction. In: F RYER, P., ET AL. (eds) Proceedings of the ODP, Scientific Results, 125. O cean D rilling Program, College Station TX, 623-662.

PENG, Z.X. \& M AHONEY, J.J. 1995. D rillhole lavas from the northwestern Deccan Traps, and the evolution of Réunion hotspot mantle. Earth and Planetary Science L etters, 134, 169-185.

Petterson, M.G. \& W Indley, B.F. 1985. R b-Sr dating of the Kohistan arc-batholith in the Trans-Himalaya of north Pakistan, and tectonic implications. Earth and Planetary Science L etters, 74, 45-57.

$--\&--1991$. Changing source regions of magmas and crustal growth in the Trans- $\mathrm{H}$ imalayas: evidence from the Chalt volcanics and $\mathrm{K}$ ohistan batholith, Kohistan, northern Pakistan. Earth and Planetary Science L etters, 102, 326-341.

- - , Crawford, M.B. \& W INdLey, B.F. 1993. Petrogenetic implications of neodymium isotope data from the $\mathrm{K}$ ohistan batholith, North Pakistan. J ournal of the Geological Society, L ondon, 150, 125-129.

Pier, J.G., Podosek, F .A., L uhr, J.F., Brannon, J.C. \& A Randa-G omez, J.J . 1989. Spinel-Iherzolite-bearing Quaternary volcanic centers in San Luis Potosi, M exico. 2. Sr and $\mathrm{Nd}$ isotopic systematics. J ournal of Geophysical Research, 94, 7941-7951.

PudseY, C.J. 1986. The Northern Suture, Pakistan: margin of a Cretaceous island arc. Geological M agazine, 123, 405-423.

R ICHARD, P., Shimizu, N . \& A LLègre, C.J. $1976 .{ }^{143} \mathrm{~N} \mathrm{~d} /{ }^{146} \mathrm{~N}$ d, a natural tracer. A n A pplication to oceanic basalts. E arth and P lanetary Science L etters, 31, 269-278.

Robertson, A.\& Degnan, P. 1994. The D ras arc Complex: lithofacies and reconstruction of a Late Cretaceous oceanic volcanic arc in the Indus Suture Zone, Ladakh Himalayas. Sedimentary Geology, 92, 117-145.

SCHÄrer, U ., H AMET, J. \& A Llègre, C.J. 1984. The Transhimalya (G angdese) plutonism in the Ladakh region: $\mathrm{a} \mathrm{U}-\mathrm{Pb}$ and $\mathrm{Rb}-\mathrm{Sr}$ study. Earth and Planetary Science L etters, 67, 327-339.

SCotese, C.R ., G Ahagan, L.M \& \& L ARson, R .L. 1988. Plate tectonic reconstructions of the Cretaceous and Cenozoic ocean basins. Tectonophysics, 155, 27-48.

SeARLE, M .P. 1991. Geology and Tectonics of the Karakoram M ountains. John Wiley \& Sons, Chichester.

Stern, R.J. \& B Boomer, S.H. 1992. Subduction zone infancy: Examples from the Eocene Izu-Bonin-M ariana and J urassic California A rcs. Geological Society of A merica Bulletin, 104, 1621-1636.

T ahirkheli, R .A.K., M attauer, M ., Proust, F.\& Tapponnier, P. 1979. The India-E urasia suture zone in $\mathrm{N}$ orthern Pakistan: Synthesis and Interpretation of R ecent D ata at Plate Scale. In: F ARAH, A \& \& EJ ONG, K .A. (eds) Geodynamics of Pakistan. G eological Survey of Pakistan, Quetta, 125-130.

T AYLOR, R.N ., M URTON, B.J \& \& N esBitT, R.W. 1992. Chemical transects across intra-oceanic arcs: implications for the tectonic setting of ophiolites. In: Parson, L.M., M urton, B.J. \& Browning, P. (eds) Ophiolites and their M odern $O$ ceanic Analogues. Geological Society of London Special Publications, 60, 117-132.

Treloar, P., Rex, D.C., Guise, P.G., Coward, M.P., Petterson, M.G., W INDLEY, B.F., L UFF, I.W. \& J AN, M.Q. 1989. K/Ar and Ar/Ar geochronology of the Himalayas in N.W. Pakistan: Constraints on timing of collision, deformation, metamorphism and uplift. Tectonics, 8, 881-909.

- -, BRodie, K.H., Coward, M.P., J AN, M.Q., K haN, M.A., K NIPE, R.J., ReX, D.C. \& W ILLiams, M.P. 1990. The evolution of the K amila shear zone, K ohistan, Pakistan. In: Salisbury, M.H.\& F ountain, D.M. (ed.) Exposed Cross-Sections of the Continental Crust. K luwer A cademic Press, A msterdam, 175-214.

- - , Petterson, M .G., J AN, M .Q. \& Sullivan, M .A. 1996. A re-evaluation of the stratigraphy and evolution of the Kohistan arc sequence, Pakistan 
$H$ imalaya: I mplications for magmatic and tectonic arc-building processes. J ournal of the Geological Society, L ondon, 153, 681-693.

W ood, D .A., M arsh, N.G., T ARneY, J., J ORon, J.L., CotTen, J. \& T Treuil, M. 1981. G eochemistry of igneous rocks recovered from a transect across the M ariana Trough, A rc, Fore-arc, and Trench, Sites 453 through 461, D eep Sea D rilling Project Leg 60. In: H ussong, D .M . ET AL. (eds) I nitial Reports of the Deep Sea Drilling Project, 60, US Government Printing Office, Washington DC, 611-646.
Y oshida, M. Zaman, H.\& A HMad, M.N. 1996. Paleopositions of K ohistan A rc and surrounding terranes since Cretaceous Time: the Paleomagnetic Constraints. Proceedings of Geoscience Colloquium, Geoscience $L a b$, Geological Survey of Pakistan, 15, 83-101.

Zartman, R.E. \& D oE, B.R. 1981. Plumbotectonics-the model. T ectonophysics, 75, $135-162$.

25 October 1996; revised typescript accepted 28 A pril 1997.

Scientific editing by N ick Rogers. 